Est Ag 40 (2005) 5-63

\title{
Comentario a la Regla de san Agustín
}

\section{CAPÍTULO QUINTO (I)}

\section{Texto del capítulo}

1. Tened vuestra ropa en un lugar común bajo la custodia de uno, de dos o de cuantos puedan bastar para sacudirla, a fin de que la polilla no la dañe. Y como os alimentáis de una única despensa, vestíos de una misma ropería. $Y$, si es posible, no sea incumbencia vuestra (determinar) la ropa que habéis de llevar según las circunstancias, (esto es,) si cada uno de vosotros recibe la prenda que había dejado o una poseída anteriormente por otro, siempre que a nadie se le niegue lo que necesita. Si, al contrario, eso se convierte en motivo de disputas y murmuraciones entre vosotros, como es el caso cuando alguien se queja de haber recibido algo peor de lo que antes había llevado y (piensa) que no se ajusta a su categoría vestir como vestía su hermano, ved en ello la prueba de cuánto os falta de aquel santo vestido interior del corazón a los que contendéis por el vestido del cuerpo. No obstante, si se ejerce la tolerancia con vuestra flaqueza, hasta el punto de recibir lo que habíais dejado, al menos tened la ropa que quitéis en un único lugar bajo custodia común.

2. De tal manera que nadie tenga ninguna actividad puramente personal, sino que todas vuestras obras las hagáis para el bien común con mayor esmero y más renovada disponibilidad que si cada uno realizaseis tareas propias para vosotros mismos. Pues lo que dice la Escritura de la caridad, esto es, que "no busca sus cosas" (1 Cor 13,5), se entiende así: que antepone los intereses comunes a los propios, no los propios a los comunes. A partir de ahí podréis conocer el alcance de vuestro progreso: será tanto mayor cuanto mejor cuidéis lo que es común que vuestras propias cosas. La consecuencia es que, en el uso de los bienes requeridos por las necesidades de esta vida pasajera, ha de prevalecer la caridad, (virtud) que permanece. 
3. De donde se infiere lo siguiente: si alguien llevase algo-una prenda de vestir, o cualquier otra cosa juzgada necesaria--, aunque fuese a sus hijos o a otras personas vinculadas a él por algún lazo íntimo residentes en el monasterio, estos no lo reciban a escondidas; antes bien, quede en. poder del prepósito para que, integrado en el fondo común, lo dé a quien tuviera necesidad de ello. [Si alguien oculta algo que le han llevado, sea condenado como reo de hurto].

4. El lavado de la ropa, realizado ya por vosotros mismos, ya por los lavanderos, hágase conforme al criterio del prepósito para evitar que el afán excesivo de llevar la ropa limpia arrastre consigo manchas en el alma, (es decir,) interiores.

5. Tampoco se niegue en modo alguno (al siervo de Dios) el baño del cuerpo, si alguna debilidad suya lo exige. Pero llévese a cabo, siguiendo sin rechistar las prescripciones médicas, de modo que, hasta contra su voluntad, haga por mandato del prepósito lo que tenga que hacerse en bien de la salud. Si, por el contrario, es él quien quiere, pero tal vez no le conviene, no transija con su antojo. Pues, a veces, incluso si resulta dañino, se cree que es provechoso lo que agrada.

6. Para concluir, cuando existe un dolor sin lesión visible en el cuerpo, créase sin dudar al siervo de Dios que manifiesta que algo le duele. No obstante, en el caso de que no exista certez a de si para curar aquel dolor conviene lo que le agrada, consúltese al médico.

7. Y no vayan a los baños o a cualquier otro lugar adonde hubiera que ir menos de dos o tres. Y quien tenga necesidad de salir deberá hacerlo no con los que él quiera, sino con quienes mande el prepósito.

8. El cuidado de los enfermos, o de los convalecientes, o de quienes, aun sin tener fiebre, padecen algún achaque, debe confiarse a alguien para que personalmente tome de la despensa lo que advierta que necesita cada uno.

9. A su vez, tanto los encargados de la despensa, como los de la ropería o de los libros sirvan sin refunfuñar a sus hermanos.

10. Pidan cada día los libros a una hora determinada. Quien los pida fuera de ella, no los reciba.

11. En cambio, los encargados de custodiar los vestidos y el calzado no difieran dárselos a quienes los pidan si carecen de ellos y los necesitan. 


\section{Plan 1}

Como hemos venido haciendo al comentar los capítulos anteriores de la Regla, también a propósito del presente estableceremos: a) algunas peculiaridades, b) cuál es su argumento específico, c) qué razón pudo impulsar al legislador a ubicar precisamente en el capítulo quinto dicho argumento, d) qué pormenores aporta el capítulo para la historia del monacato y qué datos de esta ayudan a la comprensión de sus cláusulas, e) su interpretación ascético-espiritual. Esos puntos constituirán otros tantos apartados del estudio. En cada uno de ellos comenzamos haciéndonos eco de la interpretación dada por otros comentaristas y, tras valorarla, ofrecemos nuestro propio punto de vista. Respecto de la interpretación ascéticoespiritual, nos limitamos a presentar y valorar lo expuesto por otros autores, dejando nuestra propuesta para la segunda parte de este trabajo.

\section{Peculiaridades}

El capítulo quinto tiene una fisonomía propia dentro de la Regla, que los diversos autores no han dejado de señalar. Considerándolo globalmente, L. Verheijen pone de relieve una especie de aislamiento respecto del conjunto del documento. Le distingue de los restantes el hecho de ser más concreto, ofrecer precisiones sobre la vida cotidiana en el monasterio y referirse a los diferentes servicios que reclama la vida comunitaria. Esta peculiaridad le llevó a juzgar el capítulo primero como algo "doméstico" (ménager) y casi exclusivamente monástico, y luego como el más monástico, en el sentido "técnico" del término, del documento ${ }^{2}$. Este carácter con-

1. Como los distintos comentarios a la Regla serán copiosamente citados, utilizaremos estas siglas: CILleruelo: El monacato de san Agustín y su Regla, Valladolid 1947; CillerueLO, Comentario: Comentario a la Regla de san Agustín, Valladolid 1994; SAGE: La vie religieuse selon saint Augustin, Paris 1972; ZUMKeller: The Rule of Saint Augustin with a Commentary, Wisconsin 1961; MANRIQUE - SALAS: Evangelio y Comunidad. Raíces bíblicas de la consagración a Dios en san Agustín, Madrid 1978; Trape: Sant'Agostino: La Regola, Roma 198623 van BAVEL: Agustín de Hipona: Regla para la comunidad, Iquitos [Perú] 1986; BofF: El camino de la comunión de bienes, Bogotá 1991; AgATHA MARY: The Rule of Saint Augustin. An Essay in Understanding, Augustinian Press, Villanova 1992; MARIE-AnCILlA, OP: La Règle de saint Augustin, Paris 1996; DE VOGÜÉ: Histoire littéraire du mouvement monastique dans l'antiquité, I-V, Paris, 1991- 1998.

2. Cf. respectivamente, La Règle de saint Augustin et l'éthique classique (Le praeceptum et l'étique classique), en Augustiniana 24 (1974) 5,9: 7ss NA 1,245ss); Les sermons de saint Augustin pour la carême (205-211) et sa motivation de la vie "ascetique", en Augustiniana 21 (1971) 358-404: 379 NA 1,153-200: 175; Éléments d'un Commentaire de la Règle de saint 
creto y práctico lo ponen en evidencia también otros autores ${ }^{3}$. Y precisamente por ser la parte más concreta de la Regla, la que se refiere más directamente a la vida diaria, juzgan natural que contenga elementos de la época que ya no son asumibles por las comunidades religiosas de hoy ${ }^{4}$. Este aspecto pragmático y detallista en la pluma de san Agustín resulta extraño a algún estudioso, que lo juzga más propio de san Alipio o Evodio 5 . Desde otra perspectiva y a pesar de valorar sus prescripciones como un tanto mundanas y sin relieve, no falta quien lo considera uno de los capítulos más apasionantes de la Regla, porque es en él donde san Agustín explora las implicaciones reales de buscar el bien común por encima de los intereses personales ${ }^{6}$. Nosotros hemos de añadir que nos resulta el más enigmático de todos, el de más difícil acceso a sus profundidades. El hecho de que sea tan claro u obvio en su superficie ha provocado que no se haya sentido mayor necesidad de excavar en su subsuelo. Una excavación que, efectivamente, no resulta fácil, pero sí necesaria.

\section{Argumento}

Determinar el argumento del capítulo no crea problemas a los comentaristas. En su nivel más inmediato resulta obvio que regula aspectos referentes a la ropa y al calzado, a la asistencia a los baños, a la atención de los enfermos, al desempeño de algunos menesteres dentro de la comunidad. A lo largo de sus parágrafos vemos aparecer, de hecho, los oficios de ropero, enfermero, bibliotecario y, quizá, lavandero. Cuando se quieren reunir todos estos aspectos bajo un epígrafe común, se habla de la disciplina en los bienes de uso 7; de los servicios comunitarios, o de los aspectos materia-

Augustin. XX. La charité ne cherche pas ses prôpres intérêts, en Augustiniana 34 (1984) 75144: 75 NA 2, 220-289: 220: "Le chapitre qui est le plus techniquement monastique de toute la Règle"; La Règle de saint Augustin comme prisme pour une lecture "orientée" de ses oeuvres, en NA 2,60-73: 62.

3. G. LAWLESS, The Rule of saint Augustine as a Mirror of Perfection, en Angelicum 58 (1981) 460-474: 466; VAN BAVEL, 70; BOFF, 139; F. MORIONES, Espiritualidad agustino-recoleta. II. Carácter comunitario y apostólico del carisma agustiniano, Madrid 1989, p. 260.

4. Cf. van Bavel 70; Cilleruelo, Comentario 401.

5. Cilleruelo, Comentario, 408. El autor rechaza la directa paternidad agustiniana de la Regla, juzgando que sus autores pudieron ser san Alipio o Evodio citados (cf. L. CillERUELO, Conclusiones sobre la "Regula Augustini", en Revista Agustiniana de espiritualidad 10 (1969) 49-86.

6. Agatha Mary, Looking at the Rule of saint Augustine, en Augustinian Heritage 38 (1992) 23-36: 32.

7. SAGE, 241. 
les de la vida cotidiana, o de los servicios comunitarios y la servicialidad fraterna 8 ; de servicio mutuo a nivel material, vinculado a las tareas que la vida en comunidad lleva necesariamente consigo ${ }^{9}$; del uso de los bienes y del cuidado del cuerpo o, con otra palabras, de la parte visible de la comunidad 10; del vestuario y los trabajos comunes, junto con cuestiones diversas ${ }^{11}$; del amor en acción ${ }^{12}$. Algunos autores cuyo comentario de la Regla sigue un criterio doctrinal, distribuyen su contenido dentro de diversos capítulos de sus respectivas obras ${ }^{13}$.

El proceder indicado en último lugar nos parece particularmente desafortunado porque rompe la unidad temática del capítulo. Esa unidad hay que darla por supuesta; lo contrario implicaría en el autor de la Regla una mente poco ordenada y más bien dispersa; además, no cabe hacer del presente capítulo una excepción, una vez mostrada la unidad de los tres capítulos anteriores y en espera de poder mostrarla también en los restantes; finalmente, porque la reclama la estructura del documento monástico, tal como la hemos presentado.

Las críticas que cabe hacer a las otras propuestas son varias. A algunas de ellas se les puede achacar que no circunscriben con suficiente precisión el contenido del capítulo: "Amor en acción" puede cubrir también, al menos, los capítulos sexto y séptimo, y no sólo porque en ambos aparezca explícitamente mencionado el "amor" (cf. 6,3 y 7,3); "la parte visible de la

8. L. VeRHEIJEN, "Vers la beauté spirituelle" (Par les praecepta uiuendi à la spiritalis pulchritudo. "Pythagore", le De Ordine de saint Augustin et sa Règle), en Augustiniana 22 (1972) 469-470: 469 NA I, 201-202: 201; Le De sancta Virginitate de saint Augustin et sa structure. Un complémente à l'étude du chapitre quatrième, en Augustiniana 32 (1982) 266-281: 268 NA II, 179-180: 180; Comme des amants de la beauté spirituelle. Dans Augustin évéque, en Augustiniana 32 (1982) 88-136: 92 NA II,120-122: 121. Cf. también La Règle de saint Augustin et l'éthique classique, 7ss NA 1,245ss; Les sermons, 379 NA 1,175.

9 . VAN BAVEL, 70 .

10. BoFF, 139.

11. De VoGÜé, 3,192.

12. Agatha MARY, 212. Ya más en concreto, afirma: "Now, in chapter $V, 1$, the subject of having all things in common is discussed in terms of domestic details - the sort of details that in an institutional setting become regulations but in a group of friends living together are just the-way-things-are-done" (ib., 213).

13. Así Trapè lo distribuye entre el quinto, que lleva por título: "Sobre todas las cosas que pasan, se eleve la única que permanece: la caridad" y el séptimo que versa sobre la pobreza (TRAPE, 137-144 y 155-165, respectivamente); Marie-Ancilla, a su vez, distribuye el material del capítulo entre la $2^{\text {a }}$ "Dos facetas de un mismo ideal: caridad y unidad") y la $3^{a}$ parte ("El uso de los bienes materiales"). Los parágrafos 2-4 los considera en el capítulo tercero de la segunda parte ("La unidad fundamento de un modo de vida), los parágrafos 1.3 en el capítulo primero ("Tener todo en común") y los parágrafos 5-6 en el capítulo segundo ("Dar a cada uno según sus necesidades"), ambos de la tercera parte. 
comunidad" se revela también en otros capítulos (por ejemplo, en el tercero y el séptimo); "la disciplina de los bienes de uso" cuadra igualmente con el capítulo tercero y lo mismo puede decirse de "aspectos materiales de la vida cotidiana". Otras tienen el inconveniente de que, al constar de dos partes, rompen también la unidad temática: así, "el uso de los bienes y el cuidado del cuerpo" o "vestuario y trabajo comunes; cuestiones diversas". A todas en conjunto se les puede objetar que no dan razón de por qué en el capítulo quinto vuelven a aparecer temas que ya han sido tratados con anterioridad y, algunos de ellos, en más de un parágrafo. El caso de la "ropa" puede ser paradigmático, pero no es el único. El legislador se ocupa de la "ropa" en los parágrafos primero, tercero, cuarto, noveno y undécimo del capítulo quinto, después de haber hablado ya de ella en el parágrafo segundo del capítulo primero y en los parágrafos cuarto y primero de los capítulos tercero y cuarto respectivamente. En menor escala acontece lo mismo con el tema de las salidas, del que se ocupa en el parágrafo séptimo después de haberlo tratado ya en los parágrafos segundo y sexto del capítulo cuarto. Dígase lo mismo de la atención de los enfermos, tema ya contemplado en el parágrafo quinto del capítulo tercero y al que dedica los parágrafos del quinto al octavo de este capítulo quinto. Por último, los regalos que, tras aparecer en el último parágrafo del capítulo cuarto, vuelven a resurgir en el tercero del presente.

Si no queremos ver en san Agustín un espíritu totalmente asistemático, se impone distinguir entre el aspecto material y el aspecto formal y buscar en este último lo específico del capítulo. ¿Cuál es, entonces, ese aspecto formal que unifica los variados preceptos del capítulo quinto? Tanto L. Verheijen como T. van Bavel emprendían este camino al hablar de "los servicios comunitarios y la servicialidad fraterna", el primero, y de "servicio mutuo a nivel material", el segundo. Para uno y otro el aspecto formal sería el servicio mutuo que se prestan los siervos de Dios en los aspectos materiales de la vida de la comunidad. Pero este criterio formal nos parece que no halla correspondencia con el tenor del texto. Cuadra con los cuatro últimos parágrafos, pero no parece que sea ese el aspecto al que responde lo prescrito en los anteriores 14 .

Si se analiza con detenimiento el contenido de los distintos parágrafos del capítulo, se advierte algo común a todos ellos: el legislador parece empeñado en que nadie siga la voluntad propia, sino la de otros. Y este

14. Por poner un ejemplo, ¿qué servicios prestan unos hermanos a otros en los parágrafo quinto y sexto? 
plural no debe ser pasado por alto. Pero antes de considerar lo que ello implica, entremos en el detalle. Según el parágrafo primero, no debe ser competencia personal de cada siervo de Dios determinar qué ropa ha de llevar ${ }^{15}$, pero no indica a quién compete decidirlo, aunque del parágrafo segundo del capítulo primero pudiera derivarse que es competencia del prepósito ${ }^{16}$. Según el parágrafo tercero del presente capítulo, los siervos de Dios que hayan recibido regalos, aunque sea de sus padres o allegados, han de ponerlos a disposición del prepósito, quien — se supone- determinará quién ha de hacer uso de ellos ${ }^{17}$. Quién ha de lavar la ropa, incluida la propia, lo determina también el prepósito, como lo ordena el parágrafo cuarto ${ }^{18}$. Según el quinto, quien ha de decidir si un siervo de Dios que se encuentre débil ha de ir o no a los baños es el médico, tanto si el paciente lo rechaza como si lo ansía. Al respecto, el prepósito interviene sólo si fuera necesario para apoyar con su autoridad lo prescrito por el facultativo. Explícitamente se dice que el siervo de Dios no debe transigir con su antojo ${ }^{19}$. Lo mismo vale para el parágrafo sexto: en el caso de una dolencia que sólo el paciente conozca, a la hora de determinar qué ha de hacerse para ponerle remedio, no se ha de atender sin más a su antojo, sino que, en última instancia, será siempre el médico quien lo decida ${ }^{20}$. El parágrafo siguiente continúa en la misma línea de rehusar al siervo de Dios seguir su voluntad particular: cuando tenga necesidad de ir a los baños o a cualquier otro lugar, no ha de hacerlo con quienes él quiera, sino con quienes mande el prepósito 21 . Cuando, por razones de salud, alguien necesite una dieta especial, no debe solicitarla él mismo, sino otro, encargado a tal efecto. Así

15. "Et, si fieri potest, non ad uos pertineat, quid uobis induendum pro temporis congruentia proferatur, utrum hoc recipiat unusquisque uestrum quod deposuerat, an aliud quod alter habuerat" (praec. 5,1, 1. 142-144).

16. "... et distribuatur unicuique uestrum a praeposito uestro uictus et tegumentum..." (praec. 1,2, 1.6-7).

17. "... non occulte accipiatur, sed sit in potestate praepositi, ut, in re communi redactum, cui necessarium fuerit praebeatur" (praec. 5,3, 1. 164-165).

18. "Indumenta uestra secundum arbitrium praepositi lauentur..." (praec. 5,4, 1. 166).

19. "Lavacrum etiam corporum, cuius infirmitatis necessitas cogit, minime denegetur, sed fiat sine murmure de consilio medicinae, ita ut, etiam si nolit, iubente praeposito, faciat quod faciendum est pro salute. Si autem uelit, et forte non expedit, suae cupiditati non oboediat" (praec. 5,5, 1. 169-173).

20. "... sed tamen, utrum sanandum illi dolori, quod delectat expediat, si non est certum medicus consulatur" (praec. 5,6,1.176-178).

21. "Nec ille qui habet aliquo eundi necessitatem, cum quibus ipse uoluerit, sed cum quibus praepositus iusserit, ire debebit" (praec. 5,7, 1. 180-181). 
en el parágrafo octavo 22 . En el noveno, los encargados de la despensa, de la ropería y de la biblioteca, se han de guiar, no por su arbitrio personal, sino por lo que requiera la necesidad de los hermanos ${ }^{23}$. El décimo trata de evitar la arbitrariedad en la solicitud de libros a la biblioteca: el criterio no será el antojo de cada cual ${ }^{24}$. Por último, en el undécimo, tampoco los encargados de la ropa y del calzado han de actuar arbitrariamente, sino que han de someterse a las necesidades de los demás 25.

A la vista de lo indicado, bien se puede sostener -nos parece- que el capítulo quinto de la Regla tiene como idea dominante el que ningún siervo de Dios se debe dejar llevar de su propio y exclusivo criterio. Formulado lo mismo en términos positivos, se podría entender como un capítulo dedicado todo él a la obediencia. Pero siempre que se entienda bien el concepto. En efecto, cuando en un contexto monástico se habla de dicha virtud, la mente suele pensar de inmediato en las relaciones entre la autoridad legítimamente constituida y los demás siervos de Dios. Estos no deben hacer su propia voluntad, sino la de aquella autoridad que representa a Dios. Sin embargo no es tal el caso en el presente capítulo. La obediencia que se propone en él tiene una base más amplia que la jurídica. Por supuesto, el siervo de Dios ha de renunciar a su criterio particular y seguir el del prepósito, pero no sólo el del prepósito; ha de seguir igualmente el del médico, el de los encargados de sección; tampoco estos, a su vez, se han de guiar por su propio y exclusivo criterio, sino por el de los siervos de Dios a cuyo servicio se hallan. En este capítulo, pues, se podría ver apuntado el concepto, explicitado más tarde en la Regla de san Benito, de la obediencia de todos a todos 26 .

En el recorrido que acabamos de hacer por los distintos parágrafos del capítulo pasamos por alto el segundo. Fue el único en que no señalamos ejemplos concretos de obediencia de nadie a nadie. Pero la falta de esos ejemplos concretos queda compensada de sobra con la formulación del

22. “... uni alicui debet iniungi, ut ipse de cellario petat, quod cuique opus esse perspexerit" (praec. 5,8, 1. 183-185).

23. "Siue autem qui cellario, siue qui uestibus, siue qui codicibus praeponuntur, sine murmure seruiant fratribus suis" (praec. 5,9, 1. 186-187).

24. "Codices certa hora singulis diebus petantur; extra horam qui petierit, non accipiat" (praec. 5,10, 1. 188-189).

25. "Vestimenta uero et calceamenta, quando fuerint indigentibus necessaria, dare non differant, sub quorum custodia sunt quae poscuntur" (praec. 5,11, 1. 190-192).

26. “... pongan todo su empeño en obedecerse los unos a los otros, procuren todos el bien de los demás, antes que el suyo propio" (Regla, 72); "El bien de la obediencia no deben prestarlo todos al abad, sino que también se obedecerán los hermanos unos a otros, sabiendo que por este camino de la obediencia irán a Dios..." (ib., 71). 
principio que subyace en todo cuanto ordena el capítulo: la exigencia de anteponer lo común a lo particular. Presentado en relación a un caso muy concreto, el de tener una única ropería en que guardar la ropa, su alcance se extiende a todo lo demás.

Para determinar el argumento del capítulo quinto de la Regla hay que distinguir dos planos: el último y el inmediato, que se pueden relacionar respectivamente con el ideal que el legislador tiene en mente y con la realidad concreta de la vida de cada día. El ideal cuya consecución propone, explícitamente formulado, consiste en anteponer lo común a lo privado; pero la realidad que tiene ante los ojos es la tendencia de cada persona a seguir su particular y exclusiva voluntad, criterio o antojo (cupiditas). Así, pues, en última instancia, puede considerarse como argumento específico del capítulo la exigencia de anteponer el bien común al particular. Un anteponer el bien común al particular que se traduce, en concreto, no sólo en compartir los bienes, sino también en usar y disponer de ellos según los criterios que dicte el interés común. No se trata de que un siervo de Dios renuncie absolutamente a disfrutar de los dones que Dios le otorgó, sino de que no se sitúe ante ellos con mentalidad de propietario, ni en cuanto a su uso ni en cuanto a su cuidado y administración. Cuando se habla de compartir, no hay que pensar sólo en poner a disposición de los demás los bienes que uno pueda poseer, sino también en aceptar los que posean los demás, sean materiales o espirituales, del cuerpo o del espíritu. Con referencia a los bienes del espíritu, a la luz del contenido del capítulo, el compartir se traduce en aceptar los criterios de los demás: sea del prepósito, sea del médico, sea de los encargados de los distintos servicios, sea de los siervos de Dios necesitados de algo.

Mas, para alcanzar esa meta, hay que eliminar el obstáculo principal y, en realidad, único: el mal de querer anteponer siempre el interés privado o el propio criterio particular, sin tener en cuenta a los demás, que también son beneficiarios de los dones y luces de Dios. Tal nos parece que es, pues, en instancia inmediata, el argumento del capítulo: la victoria sobre el sentimiento de propiedad particular en relación con el uso, cuidado y administración de los bienes materiales. Lo presentamos en negativo, porque el legislador tiene como primera intención poner remedio a un mal.

En efecto, en el presente capítulo sigue el mismo procedimiento que en los anteriores. En el segundo, en que contemplaba el ideal de la oración, se centró en eliminar lo que la impide o dificulta; en el tercero, en que tenía ante sus ojos un aspecto del ideal de la salud plena, se centró en la falta de salud y en cómo conseguir esta; en el cuarto, en que consideraba otro aspecto de la salud plena, el significado por la castidad, se centró en 
cómo no perderla o, en su caso, recuperarla. Lo mismo cabe decir del presente: tiene en mente el ideal de la comunión de bienes, pero se centra en combatir lo que se le opone: el sentimiento de propiedad particular.

\section{Ubicación en la estructura de la Regla}

La pregunta que ahora cabe hacerse es por qué el legislador introduce este argumento precisamente aquí y no en otro lugar de la Regla. Los pocos autores que se ocupan de ello no le dedican excesivo espacio. Para el presente caso vale lo afirmado a propósito del capítulo cuarto. Si algo dicen al respecto, es más bien de paso; raro es el que entra un poco más a fondo en la cuestión. Nos fijamos en tres autores: M. Neusch, Agatha Mary y A. de Vogüé y seguimos el orden cronológico de sus respectivas publicaciones.

M. Neusch, buscando una estructura armónica para el conjunto de la Regla, considera como una unidad los capítulos quinto y sexto que contrapone al capítulo cuarto. En su planteamiento, el argumento del capítulo quinto es el complemento lógico del capítulo cuarto. Después de haber tratado el legislador en este último de la vida fuera del monasterio, en el quinto y sexto se ocupará de la vida dentro de él, considerando dos aspectos: los servicios (cap. 5) y el perdón mutuo (cap. 6) ${ }^{27}$.

A propósito de los dos últimos parágrafos del capítulo cuarto, Agatha Mary indicaba, según vimos ${ }^{28}$, que tenía valor de puente entre los cuatro primeros capítulos y los restantes. En consecuencia, con el capítulo quinto comienza una segunda parte. Lo que, según la autora, justifica hablar de una segunda parte, es el hecho de la mayor presencia de las reglas que rigen la comunidad monástica, casi ausentes en lo que precede. Las partes están constituidas en función de la dialéctica no reglas/reglas. Justifica tal división también el hecho de que, en lo que precede, el centro del interés estaba en la construcción de la unidad entre los hermanos, mientras que, a partir del capítulo quinto, la preponderancia la obtiene el amor. La división ahora se establece en función de la dialéctica unidad/amor. Mientras en la primera parte en el documento monástico aparece el siervo de Dios con todo el trasfondo de influencias que acarrea y le facilitan u obstaculi-

27. La structure de la Règle, en Itineraires Augustiniennes 4 (1990) 12-19: 14. El capítulo cuarto lo desdobla en dos partes, una dedicada a las mujeres y otra a la corrección fraterna, para mantener el paralelismo con su pendant, que incluye también dos partes: los capítulos quinto y sexto.

28. Cf. Estudio Agustiniano 38 (2003) p. 548. 
zan la integración en el nuevo estilo de vida, en la segunda explora la vida corporativa de la comunidad 29 .

Una de las estructuras que sostienen la Regla es, según A. de Vogüé, el texto de 1 Tim 6,8, al que san Agustín se refiere en el capítulo primero ${ }^{30}$. Ese texto bíblico daría razón, según el sabio benedictino, del sucederse de los temas específicos de los capítulos tercero, cuarto y quinto. En efecto, según el texto paulino, teniendo qué comer y qué vestir el cristiano ha de darse por contento ${ }^{31}$. Como el legislador se ocupó del alimento en el capítulo tercero, al vestido le dedicó los capítulos cuarto y quinto, tratando en cada uno de ellos de una específica virtud que mantiene relación con él: la castidad en el capítulo cuarto, y la pobreza en el capítulo quinto, el que ahora nos interesa y ocupa. Sólo que, en éste, la cuestión del vestido será tratada con más detalles y puesta en mayor relación con la virtud en causa. San Agustín comienza y acaba el capítulo hablando de vestidos 32 .

La propuesta de M. Neusch de vincular el capítulo cuarto al quinto sobre la base de que el primero se ocupa de la vida fuera del monasterio y el segundo de la vida fuera de él no parece asumible, porque, de una parte, este último contempla también la vida fuera del monasterio ${ }^{33}$, y la vida dentro de él la contemplan no sólo los capítulos quinto y sexto, sino todos los demás. El criterio fuera/dentro no nos parece que sirva aquí. Agatha Mary ha advertido bien el cambio que se da en el capítulo quinto, y precisamente en la dirección social, pero no acierta al incluir el capítulo octavo en el mismo saco que el quinto, sexto y séptimo. Aunque en el capítulo octavo sí aparezca el concepto del amor, dominante en esta segunda parte, a él no cabe aplicarle otros criterios que, según la autora, justifican que se hable de una sección nueva. Es difícil, en efecto, ver en él una exploración de la vida corporativa de la comunidad, o la presencia de las reglas que dis-

29. Agatha Mary, 211-212.

30. Cf. praec. 1,3, 1.6-7. Texto latino en nota 16.

31. Sin mencionar directamente 1 Tim 6,8, también V. Grossi establece una relación entre los capítulos tercero, cuarto y quinto, sobre la base de las necesidades del cuerpo. Cf. Ascetica del corpo e antropologia nella "Regula ad servos Dei" (cc. 3-5) di S. Agostino, en Mémorial Dom Jean Gribomont (1920-1986), Studia Ephemeridis "Augustinianum", Roma 1988, 315-320: 316.321.

32. DE VoGÜÉ, 3,174; cf. praec. 5,1.11. El autor señala otra relación muy concreta entre el capítulo cuarto y el quinto: el delito de recibir secretamente regalos de una mujer (praec. 4,11) y recibir también ocultamente vestidos u otros objetos regalados por gente de fuera ( $i b$. 5,3). Para él "Ces deux réprobations analogues du délit de "réception occulte" renforcent la connexion des deux sections, qui se rapportent l'une l'autre, on s'en souvient, au même objet materiel: l'habit" (ib., 192).

33. Cf., al menos, los parágrafos 5,4-7. 
tinguen esta segunda parte de la primera. Tampoco nos parece aceptable el planteamiento de De Vogüé. Considerar la doble necesidad de alimento y vestido para coordinar y diferenciar los capítulos tercero de una parte (alimento), y cuarto y quinto de otra (vestido) pudiera ser admisible sólo si el tema del vestido no apareciese ya en el capítulo tercero ${ }^{34}$. Además, establecer una conexión especial entre el capítulo cuarto y el quinto sobre la base de que ambos reprueban la "recepción oculta" de regalos, tampoco se sostiene porque no está asegurado, contra lo que él afirma, el mismo objeto material: la ropa. Sin duda, el parágrafo tercero del capítulo quinto incluye explícitamente entre los posibles regalos alguna prenda de vestir, pero no es ese el caso del último parágrafo del capítulo cuarto que habla de cartas y de "regalillos", que no necesariamente hay que entender referidos a prendas de vestir.

Nuestro punto de partida es que con el capítulo quinto la Regla entra en una nueva perspectiva, esto es, adquiere una nueva dimensión social de que antes carecía. Y en ello estamos de acuerdo con Agatha Mary. Por supuesto, cuando se vive en comunidad, hasta lo a primera vista más personal adquiere connotaciones sociales. $\mathrm{Y}$ así lo hemos visto en el capítulo segundo, que contempla cómo el obrar de unos se puede convertir en impedimento para la oración de otros; o en el tercero, en que el trato especial dado a algunos provoca el rechazo de otros; o en el cuarto, en que unos pueden modificar conductas de otros. Pero, aun contempladas esas connotaciones sociales, la perspectiva es individual: la oración del siervo de Dios, su salud personal. Los demás aparecen al servicio del individuo. En el capítulo quinto, junto con el sexto y el séptimo, ese aspecto social, en cambio, aparece en primer plano, aunque desde perspectivas diferentes. Es esta nueva dimensión social la que da razón de la ubicación a esta altura de la Regla del tema de la comunión de bienes o, en negativo, del postergar el antojo personal. Después de haberse ocupado de los aspectos más personales del siervo de Dios, el legislador se propone ahora regular los aspectos sociales.

Es el momento de traer aquí, como a propósito de los capítulos anteriores, la estructura general de la Regla. Recordemos que el capítulo quinto se integra en la sección B de la misma, y específicamente en su "unidad" tercera de la que es parte junto con los capítulos sexto y séptimo. Ahora bien, si la primera unidad contemplaba al siervo de Dios en su dimensión espiritual y la segunda en su dimensión física, la tercera le contempla en su

34. "... aliquid alimentorum, uestimentorum, stramentorum..." (praec. 3,4, 1. 59). 
dimensión social. $\mathrm{O}$, vista desde otra perspectiva, si la primera se ocupaba de regular las relaciones con Dios y la segunda de las relaciones consigo mismo, la tercera se centra en las relaciones con los demás. Por tanto, si el capítulo quinto trata de lo que trata, no es porque san Agustín quiera ocuparse de la vida dentro del monasterio, después de haberse ocupado de la vida fuera de él, ni porque, tras haber considerado el modo de vestir en relación con la castidad, quiera considerarlo ahora desde la perspectiva de la pobreza.

La pregunta es otra: ¿por qué la dimensión social ocupa la tercera "unidad"? La respuesta puede venir de la jerarquía de valores propia del Santo. Partiendo de la primacía de Dios en todos los aspectos, resulta lógico que otorgue el primer lugar a la relación con él; tanto más, si se tiene en cuenta que dicha relación va vinculada a la dimensión espiritual a la que él, alimentado de platonismo, asignaba tanta importancia. Más difícil parece establecer el orden de preferencia entre la relación con uno mismo y la relación con los demás. La vinculación, casi espontánea, entre la relación con uno mismo y el egoísmo y la relación con los demás y la caridad podría llevar a anteponer la relación con los demás a la relación con uno mismo. Pero tal planteamiento sería falso. De una parte, igual que puede darse una relación inadecuada con uno mismo, puede darse una relación inadecuada con los demás, e igual que puede darse una relación adecuada con los demás, pueda darse una relación adecuada con uno mismo. De otra parte, ha de tenerse en cuenta que es el mismo evangelio el que propone el justo orden de estas relaciones: el criterio para amar al prójimo, es el amor a uno mismo: "Amarás al prójimo, como a ti mismo" (Mt 22,39). Aquí puede estar la explicación de por qué el contenido del capítulo quinto, en concreto, aparece en la Regla a continuación del contenido del tercero y cuarto.

Resuelta -así nos parece- la cuestión de por qué el contenido del capítulo quinto sigue, y no precede, al de los anteriores, surge otra de naturaleza similar. Dando por hecho que los capítulos quinto, sexto y séptimo forman una "unidad" y que los tres contemplan la relación del siervo de Dios con los demás o, con otras palabras, su dimensión social, cabe preguntar a qué criterio obedece el orden en el interior de la "unidad" misma. Es una cuestión que dejamos simplemente planteada, esperando darle respuesta una vez examinados los tres capítulos que integran la "unidad". 


\section{Estructura del capítulo}

El capítulo quinto es, de toda la Regla, aquel cuya estructura interna resulta más difícil de detectar. Y, por supuesto, no hay acuerdo entre los autores al respecto.

A. Zumkeller no menciona para nada la estructura del capítulo. Pero, si juzgamos por los epígrafes de su comentario, la estructura que parece presuponer consiste en la simple juxtaposición de tres temas diferentes: la pobreza y el compartir (par. 1-4), la limpieza y la salud (par. 4-7), el espíritu monástico de trabajo (par. 8-11).

Tampoco A. Sage habla explícitamente de estructura, pero también podemos derivar una de sus mismos epígrafes. Entiende que el capítulo se ocupa de los bienes de uso y, a partir de ahí, contempla dos partes en él: una que versa sobre su mantenimiento dentro del monasterio (par. 1), otra sobre su mantenimiento fuera de él (par. 4-8). Esas dos partes se completan con otras dos: la primera, dedicada a la "regla de oro" que ha de regular todo (par. 2-3); la segunda, a los oficios, a través de los cuales se ejecuta (par. 9-11). Aunque su propuesta tiene cierta unidad, no es demasiado armónica, pues su última parte rompe los equilibrios.

T. van Bavel sí se plantea la cuestión de la estructura y presenta la siguiente: 1 . Comunidad y vestidos; 2 . preocupación por el interés de la comunidad como criterio de progreso; 3 . baños públicos y atención a los enfermos; 4. preocupación mutua en todas las necesidades corporales ${ }^{35}$. Pero lo que en realidad encontramos aquí es una simple sucesión de temas tratados, sin la conexión lógica y armónica entre ellos, necesaria para que se pueda hablar de estructura.

A. de Vogüé se limita también a indicar la concatenación de los temas: lo prescrito sobre el vestuario común conduce al tema del trabajo común, exigencia de la caridad. A su vez, el lavado de los vestidos lleva al del cuerpo, y éste a avisos sobre las salidas y al cuidado de los enfermos; por último, unas advertencias finales a los distintos encargados ${ }^{36}$. La crítica hecha al anterior autor, puede valer también para este: se ciñe a los temas tratados, es decir, al aspecto exterior, sin entrar en lo interior. Pero, aunque el sabio benedictino no haya desarrollado la intuición, apunta, creemos, en la buena dirección cuando señala que las prescripciones connexas del capítulo "denotan frecuentemente la preocupación por quitar a los individuos el

35. VAN BAVEL 70-71.

36. DE VoGÜÉ, 3,174-175. 
poder de seguir sus deseos y de hacer lo que quieren, sometiéndolos a la voluntad de otro" 37. A nuestro parecer, su error está en no haber generalizado, pues, al usar el adverbio "frecuentemente", pone límites a lo afirmado 38 .

Agatha Mary utiliza una imagen musical para caracterizar el capítulo, viendo aparecer en los distintos parágrafos los diferentes integrantes de una orquesta con su sonido específico. En el parágrafo primero se hallan quienes se quejan de los vestidos; en el segundo aparece el sonido del beneficio personal; en el tercero, el monje que quiere engañar a los otros; en los cuarto y quinto, advertencias contra el autoengaño; en el sexto, se oye el grito del temeroso; en el séptimo, el tema de la cautela, que hace de puente para con los restantes; el octavo ofrece una guía para el cuidado al enfermo y abre los resortes de la comunidad para ofrecer la ayuda requeri$\mathrm{da}$; los tres últimos indican algunos de los diferentes modos como la comunidad se empeña en la única empresa de vivir la vida común en el amor. Pero la autora no se ocupa sólo de los detalles; piensa también en el movimiento general de la pieza. Este se caracteriza por trasladar el centro de atención desde el solista que expresa su particular tema propio hasta una plena armonía en que cada individuo se convierte en una parte intrínseca del todo. O con otras palabras, lleva a los lectores del área del interés personal (par. 1-7) al de la aceptación y participación, en que la singularidad tiene un alto valor y donde la solidaridad es de capital importancia ${ }^{39}$. La autora ha advertido bien la diferencia existente entre los parágrafos 1-7 y los parágrafos 8-11, pero no ha acertado con el criterio que funda la distinción.

Ha llegado el momento de presentar nuestra visión del problema. Partimos de que el capítulo ha de tener una estructura nítida, al menos internamente. Esa estructura ha de unificar todos los parágrafos o, si se quiere, los distintos temas que aparecen en ellos. Al mismo tiempo, la estructura interna no puede desvincularse del argumento del capítulo a cuyo servicio ha de estar. Antes hacíamos referencia a la dificultad que entraña el descifrar la estructura del capítulo. Si volvemos a recordarlo aquí es para significar que no asignamos un valor absoluto a nuestra propuesta.

Para llegar a nuestro objetivo, nos parece oportuno comenzar con algunas consideraciones de naturaleza literaria. Tomando pie de la edición

37. DE VoGÜÉ, 3,175.

38. De hecho, en nota remite sólo a los parágrafos 3.4.5.7.8.

39. Agatha Mary, 251-252. 
crítica de L. Verheijen, en el capítulo se pueden establecer cuatro secciones. La primera incluye los parágrafos 1-3; la segunda, los parágrafos 4-7; la tercera, los parágrafos 8-9; la cuarta y última, los parágrafos 10-11. El criterio seguido para establecer la división no ha sido otro que la presencia o ausencia de conjunciones o adverbios que vinculen o no un parágrafo al anterior. En esquema:

$1^{\mathrm{a}}$. sección: par. 1-3.

$2^{a}$. sección: par. $2-4$.

$3^{\mathrm{a}}$. sección: par. 8-9.

$4^{\text {a }}$. sección: par. 10-11.

En efecto, el parágrafo primero, a parte de no abrir con ninguna conjunción, introduce por necesidad una sección; el parágrafo segundo va unido al anterior por el ita... ut consecutivo; y el tercero por el giro consequens est que lo vincula también a lo anterior.

El parágrafo cuarto comienza sin conexión alguna de carácter literario con el anterior. En cambio, el parágrafo quinto está vinculado al anterior por el adverbio etiam; el sexto, por la conjunción denique, y el séptimo por la conjunción nec.

El parágrafo octavo, de nuevo, se halla libre de toda conexión literaria con el que le precede; en cambio, el noveno aparece vinculado al anterior por la conjunción pospositiva autem.

El parágrafo décimo, por último, carece también de toda vinculación literaria al anterior; no así el undécimo, cuya conexión con el décimo la expresa la conjunción uero.

Nuestro paso siguiente consiste en establecer la relación que existe entre esta estructura literaria y el argumento del capítulo, que es, según dijimos antes, el posponer la voluntad particular. Veamos cómo acontece eso.

Sección primera (par. 1-3). A nivel material, la sección trata de la ropa de vestir, tanto en lo que se refiere a su uso/reparto como a su conservación. En el caso de los donativos recibidos (par. 3), junto a la ropa de vestir se contemplan otros objetos no especificados. Respecto al tema formal capítulo, el legislador ordena que, a poder ser, no sea incumbencia de cada siervo de Dios la ropa que ha de llevar según las circunstancias; que la custodia de la misma no sea responsabilidad directa del usuario, sino de los encargados que miran por la de todos en conjunto; que el uso que se deba dar a los donativos que pudieran recibirse no lo determine quien los recibe, sino el prepósito. 
Aunque en esta síntesis no hayamos incluido nada concreto del parágrafo segundo, no debe tomarse como una dificultad, por dos razones. Una, porque -como ya indicamos- todo él está centrado en motivar que prevalezca lo común sobre lo particular; otra, porque propiamente no debería formar un parágrafo aparte, dado que no hace sino sacar y justificar las conclusiones de lo preceptuado en el apartado anterior ${ }^{40}$.

El siervo de Dios que cumple lo prescrito en dichos parágrafos renuncia a su voluntad particular. ¿En favor de qué otra voluntad? Respecto de lo mandado en el parágrafo tercero, no hay problema; en favor de la del prepósito. Menos clara es la respuesta a propósito del parágrafo primero. Si no ha de ser incumbencia de cada siervo de Dios determinar qué ropa ha de vestir, ¿de quién es incumbencia? Desde los parágrafos noveno y undécimo podría pensarse en los encargados, pero no necesariamente, como veremos; desde el parágrafo segundo del capítulo primero, en cambio, habría que pensar en el prepósito. Por razones de estructura, juzgamos más probable esta segunda opción. En todo caso, volveremos sobre el tema.

Sección segunda (par. 4-7). Las normas concretas que se dan aquí se refieren, primero, al lavado de la ropa (par. 4), luego al uso de los baños (par. 5-7). Más que de bienes, se trata de dos servicios de que el siervo de Dios puede disponer. En relación con el tema del capítulo, de lo prescrito resulta que el siervo de Dios no ha de seguir su personal criterio respecto del lavado de la ropa (par. 4), de la visita o no a los baños públicos (par. 5), de la terapia adecuada para ciertos males físicos (par. 6), y de quiénes han de acompañarle cuando tenga que salir fuera (par. 7). Según lo prescrito en esta sección, el siervo de Dios ha de someter su criterio particular al del prepósito (par. 4 y 7 ) y al del médico (par. $5^{41}$ y 6 ).

Sección tercera (par. 8-9). En estos dos parágrafos el legislador se ocupa del cuidado alimentario de quienes no gozan de buena salud y de cómo han de servir a los hermanos los encargados de la despensa, la ropería y la biblioteca. El legislador ha entrado en un ámbito nuevo, el de la administración de los bienes de la comunidad. Para entender bien la rela-

40. Se puede equiparar con el último punto del parágrafo quinto donde justifica lo ordenado previamente en el mismo parágrafo. La diferencia está sólo en la extensión, pues, mientras en este se trata de sólo una línea, en aquel ocupa varias.

41. Propiamente el legislador no habla de la persona concreta del médico, sino en abstracto, de la ciencia médica. Aquí el prepósito actúa sólo en el caso de que el siervo de Dios no acepte la prescripción médica. 
ción con el argumento del capítulo, no debe pasarse por alto el carácter adversativo, esto es, de oposición, de la conjunción autem que establece la relación entre el parágrafo octavo y el noveno que integran la sección. Uno y otro parágrafo responden al argumento del capítulo, pero de forma contrapuesta. En el octavo, el siervo de Dios que no goza de buena salud ha de renunciar a su criterio en cuanto a lo que ha de tomar de la despensa en favor del criterio del enfermero; en el noveno, en cambio, los encargados de la despensa, ropería y biblioteca han de renunciar al propio criterio en favor del criterio de los hermanos necesitados a quienes han de servir sin refunfuñar.

Sección cuarta (par. 10-11). Estos parágrafos siguen dando normas sobre cómo han de actuar quienes están encargados de la biblioteca y ropería; es decir, se mantienen en el ámbito de la administración de los bienes. Lo que acabamos de decir a propósito de la conjunción adversativa tamen, vale también para la presente sección. La diferencia está en que ahora la conjunción es uero, cuyo valor es asimismo adversativo. Según ello, estos dos parágrafos se adecuan al argumento del capítulo en este sentido: en el parágrafo décimo, el siervo de Dios ha de renunciar a su criterio personal en cuanto a la hora de sacar libros de la biblioteca en favor del criterio de los encargados 42; en el undécimo, en cambio, son los encargados los que han de renunciar a su criterio personal en cuanto al tiempo, en favor del criterio de quien necesita lo solicitado.

Pero todavía es posible entrar en más detalles. Lo que da unidad interior a los preceptos del capítulo quinto es la voluntad del legislador de que el siervo de Dios someta su criterio al de otros. Estos "otros" se encuadran en dos categorías: una jerárquica y otra no jerárquica, doble categoría que divide el capítulo en dos partes (par. 1-7 y 8-11 respectivamente). A su vez, el capítulo contempla dos clases de jerarquía: una jurídica (el prepósito) y otra profesional (la medicina/el médico). Esta doble modalidad jerárquica da origen a una subdivisión en la parte respectiva: en un primer momento, actúa sólo la jerarquía jurídica (par. 1-3); en un segundo momento, intervienen las dos (par. 4-7, en forma de quiasmo ${ }^{43}$ ).

La modalidad no jerárquica se presenta también subdividida, en cuanto que contempla dos aspectos diferentes de una misma realidad material,

42. Al respecto no tiene mayor importancia si el horario lo ha impuesto el bibliotecario u otra persona o instancia. En todo caso, él se atiene al horario establecido.

43. En los par. cuarto y séptimo el prepósito; en los quinto y sexto, el médico. 
el servicio de unos hermanos a otros: mientras los parágrafos octavo y noveno versan sobre el hecho en sí, los dos siguientes sobre el momento en que debe hacerse. Pero el criterio formal es siempre el mismo: anteponer el criterio de los demás al propio.

La estructura del capítulo, pues, puede quedar recogida en los dos esquemas que presentamos a continuación.

\section{Referido al aspecto material:}

I. Par. 1-3: Puesta en común (uso y custodia) de los bienes materiales.

II. Par. 4-7: Utilización de determinados servicios (lavandería y baños).

III. Par. 8-11: Administración de los bienes materiales (alimentos, ropa, calzado, libros):

1. Par. 8-9: el cómo.

2. Par. 10-11: el cuándo.

\section{Referido al aspecto formal:}

I. Anteponer el criterio de la "jerarquía" al propio (par. 1-7).

1. La jerarquía jurídica: el prepósito (par. 1-3).

2. La jerarquía jurídica y profesional: prepósito y médico (par. 4-7).

a. Anteponer el criterio del prepósito (par. 4).

b. Anteponer el criterio del médico (par. 5).

c. Anteponer el criterio del médico (par. 6).

d. Anteponer el criterio del prepósito (par. 7).

II. Anteponer el criterio "no-jerárquico" de otros (encargados de los servicios y demás hermanos) al propio. (par. 8-11).

1. Con referencia al servicio en sí (par. 8-9).

a. El criterio del encargado ha de prevalecer sobre el del siervo de Dios necesitado (par. 8).

b. El criterio del siervo de Dios necesitado ha de prevalecer sobre el de los encargados (par. 9).

2. Con referencia al momento de prestar el servicio (par. 10-11).

a. El criterio del encargado ha de prevalecer sobre el del siervo de Dios necesitado (par. 10).

b. El criterio del siervo de Dios necesitado ha de prevalecer sobre el de los encargados (par. 11). 


\section{Datos desde y para la historia}

Ya mencionamos cómo los comentaristas ponen de relieve el carácter eminentemente práctico de este capítulo de la Regla. Es el que más nos acerca a la realidad de la vida diaria del monasterio destinatario del documento. Esta circunstancia hace de él una fuente valiosa para la historia del monacato antiguo, èspecíficamente del africano. La información que aporta abarca diversos ámbitos. El historiador encuentra en él datos referidos al edificio, al personal de servicio en el monasterio, a los diversos oficios desempeñados en él, al régimen de salidas, a los horarios, al trato con los enfermos, al uso dado a los donativos recibidos, al reparto y lavado de la ropa, etc. Distintos aspectos que irán saliendo a medida que examinamos cada uno de los parágrafos.

\subsection{Parágrafo primero}

Este primer parágrafo es particularmente rico en información. La Regla nos había permitido conocer ya una dependencia del monasterio, el oratorio ${ }^{44}$. El presente parágrafo nos permite conocer la existencia de otras dos: la ropería, en que se custodiaba la ropa del conjunto de los hermanos ${ }^{45}$, y la despensa, aquí mencionada por primera vez, pero que volverá a aparecer en los parágrafos octavo y noveno ${ }^{46}$. Hay que anotar que, si el disponer de una despensa común parece lógico, no lo es tanto el tener una ropería común.

Una vez constatada la existencia de una ropería común, es natural pensar que hubiese siervos de Dios encargados de ella. El presente parágrafo informa sólo sobre el número de ellos y sobre una de sus funciones ${ }^{47}$; otros parágrafos darán información ulterior. En cuanto al número, ordena que haya uno o dos, o cuantos fueren necesarios. El legislador piensa, así parece, que uno o dos eran suficientes; no obstante, no excluye que pudieran necesitarse más. El número requerido puede depender, obviamente, de varios factores: de la laboriosidad de los encargados, del tiempo de que dispongan y, por supuesto, del volumen de trabajo que haya que desarrollar.

44. Cf. praec. 2,2, 1. 37-38.

45. "Vestes uestras in unum habete... sic induimini ex uno uestiario... in uno tamen loco... habete quod ponitis" (praec. 5,1, 1. 139.141.151).

46. "... et sicut pascimini ex uno cellario...; ut ipse de cellario petat...; siue autem qui cellario... praeponuntur..." (praec. 5,1, 1.141.184.186-187).

47. "... sub uno custode uel duobus uel quot sufficere potuerint ad eas excutiendas" (praec. 5,1, 1. 139-140). 
Dando por supuesto que el legislador contaba, al menos, con la laboriosidad normal de los siervos de Dios y que conocía el tiempo de que disponían según el horario de la comunidad, cabe preguntarse por el sentido de la acotación "cuantos puedan bastar". La respuesta bien pudiera ser esta: ese particular revela la confianza que tenía el santo en que su comunidad iría creciendo progresivamente. En consecuencia, aunque en el momento en que escribía podía bastar uno, o incluso dos, pues la comunidad aún sería de reducidas dimensiones, en el futuro, una vez aumentado el número de miembros, sería necesario poner más encargados. Por otra parte, dando por descontado que la ropa de que podrían disponer al menos la mayoría de los siervos de Dios, provenientes de las capas humildes de la sociedad, no podía ser mucha, el que se pudiesen necesitar ya dos personas puede entenderse como indicador de una comunidad numéricamente significativa. La tarea que tienen asignada es presentada únicamente como de custodia; en concreto, esa custodia conlleva el sacudirla para que no la dañe la polilla.

En el parágrafo el legislador ordena que, a ser posible, no sea incumbencia de cada siervo de Dios determinar qué ropa ha de llevar según los diferentes tiempos. Lo que ahora nos interesa no es la razón de ese precepto sino el dato en sí. Quisiéramos saber de quién es incumbencia, pero el texto no lo indica. En principio pudiera pensarse en los encargados; pero esta opción parece que debe descartarse por varias razones: una, porque la única función que les ha confiado inmediatamente antes es la de atender a su cuidado y conservación. Es cierto que en el parágrafo noveno se les ordena que sirvan a sus hermanos sin murmurar; pero ello no implica necesariamente que fueran ellos los que indicasen qué debía llevar cada uno; en efecto, puede entenderse también en el sentido de que debían servir a los demás lo que la persona competente hubiera señalado para cada uno. Una segunda razón la encontramos en el parágrafo tercero del capítulo primero. En él se indica que es función del prepósito el distribuir a cada uno el alimento y el vestido ${ }^{48}$. La misma estructura indicada con anterioridad da por supuesta esta interpretación.

Las murmuraciones a que daba origen el reparto de la ropa es un testimonio más de cuán mezquina se muestra a veces la condición humana. Pero no es ese el aspecto que ahora nos ocupa. Ya tratamos a propósito del primer parágrafo del capítulo cuarto la cuestión de si los siervos de Dios

48. "... et distribuatur unicuique uestrum a praeposito uestro victus et tegumentum..." (praec. 1,3, 1.6-7). 
vestían de un modo uniforme, esto es, si llevaban una especie de hábito monástico. No es preciso, pues, volver sobre ello. Aquí nos limitamos a señalar que, contra lo que pudiera parecer a primera vista, el hecho de que determinados siervos de Dios reclamen poder seguir llevando lo que ellos trajeron al monasterio, cuando entraron en él, no excluye ese modo de vestir uniforme. El texto deja entrever que el aferrarse de algunos a las prendas que ellos habían llevado con anterioridad tenía su fundamento en la superior calidad de las mismas; de ahí que consideren como un rebajar su categoría el obligarles a llevar determinadas prendas que antes había llevado algún otro hermano ${ }^{49}$. Pero el que la calidad sea superior no implica que su forma sea diferente. Aún vistiendo todos de la misma forma, el género de las prendas podía reflejar muy bien el diferente status social de cada uno antes de entrar en el monasterio.

En otro orden de cosas, el parágrafo deja entrever una comunidad de reciente fundación en que las costumbres anteriores mantienen aún su peso y la fusión de las clases sociales es aún imperfecta 50 .

\subsection{Parágrafo segundo}

Al formular principios más que preceptos concretos, el parágrafo segundo aporta poca información para conocer la vida de la comunidad destinataria de la Regla. No obstante, no debe pasarse por alto el hecho de que el legislador haga referencia, aunque sea de soslayo, al trabajo de los siervos de Dios. Es cierto que, a diferencia del Ordo monasterii, la Regla no prescribe en parte alguna el trabajo manual ${ }^{51}$, pero con igual certeza hay que admitir la existencia del trabajo manual en el monasterio. De una parte, era elemento tradicional en la vida monástica; de otra, se puede derivar del hecho de que aquí el Santo utilice el verbo operor y el sustantivo opus ${ }^{52}$, el mismo que aparece en el título de la obra del Santo dedicada al trabajo manual de los siervos de Dios residentes en Cartago 53. De hecho, lo menciona en relación con una tarea de naturaleza física, como es el custodiar la ropa, que conllevaba el sacudirla para que no se apolillase. Bajo el plural opera se pueden ocultar múltiples actividades realizadas por

49. “... cum queritur aliquis deterius se accepisse quam prius habuerat et indignum se esse qui ita uestiatur, sicut alius frater eius uestiebatur" (praec. 5,1, 1. 145-147).

50. De Vogüé, 3,192.

51. DE VogüÉ, 5, 242.

52. "... ut nullus sibi aliquid operetur, sed omnia opera uestra in commune fiant..." (praec. 5,2, 1.153-154).

53. De opere monachorum. 
los moradores del monasterio. Tratándose de un monasterio de laicos, sobre los que no pesaba la carga del ministerio pastoral, es lógico pensar que el trabajo manual ocupase una parte importante del horario del día. Resulta difícil aceptar que san Agustín no aplicase a "su" monasterio la "filosofía" que propuso a los monjes de Cartago en la obra El trabajo de los monjes 54 . De otra parte, procede no olvidar que el Ordo monasterii prescribe varias horas diarias al trabajo manual 55 . De las múltiples tareas posibles, sólo conocemos las que señala en el presente capítulo, necesarias para la marcha normal del monasterio. Pero sabemos que existían otras, ya dentro de la casa ya, posiblemente, fuera. El parágrafo segundo del capítulo segundo contempla la posibilidad de que alguien pueda estar haciendo en el oratorio algo que impida hacer oración en él fuera de las horas establecidas en el horario ${ }^{56}$. La Regla no menciona explícitamente el trabajo fuera de casa, pero en esa dirección puede orientarse el que hable por dos veces de salidas fuera del monasterio. Aunque lo hace de forma genérica, sin especificar lo más mínimo ${ }^{57}$, bien pudiera tratarse de salidas relacionadas de un modo $u$ otro con el trabajo ${ }^{58}$.

Si el Santo no es más explícito al respecto puede deberse, de una parte, a la naturaleza del documento monástico, que tiene más de programa espiritual que de reglamentación de la vida diaria a nivel exterior; de otra, a que no constituía problema en la comunidad. Como la mayoría provenían de un estrato social bajo, el trabajo había sido su hábitat natural y como tal lo mantenían. La diferencia con los monjes de Cartago, también ellos provenientes en su mayor parte de la misma capa social, se hallaría en que éstos estarían ya contaminados con otros planteamientos más espiritualistas que no habían llegado a Hipona. A este respecto también podría tener su peso el hecho de que la de Hipona era una comunidad aún joven. Lo cierto es que, con relación al trabajo, las dos recomendaciones que el legis-

54. Según De Vogüé, un pasaje de ep. 126,10 (inpares sumus nec aliquid ad sustentacula uitae huius operari nostris manibus...) permite tal vez entrever en los monjes laicos de Hipona una práctica más bien ligera de la ley del trabajo manual (DE VoGÜÉ, 5,242).

55. "Operentur a mane usque ad sextam" (Ordo mon. 3).

56. No obstante, en este caso no emplea el verbo operor, sino el más genérico ago (cf. praec. $2,2,1.36 .40)$.

57. Una en el presente capítulo: "Nec eant ad balneas, siue quocumque ire necesse fuerit..." (praec. 5,7, 1.179); otra, en el capítulo cuarto: "Quando ergo simul estis in ecclesia et ubicumque ubi et feminae sunt..." (praec. 4,6, 1. 103-104).

58. El Ordo monasterii habla de quienes salen para vender lo que produce el trabajo realizado dentro del monasterio (cf. $\mathrm{n}^{\circ} 8$ ). 
lador hace se refieren, una, al espíritu con que deben hacerlo y, otra, al lugar donde no deben hacerlo ${ }^{59}$.

\subsection{Parágrafo tercero}

Entrar en el monasterio implicaba renunciar al mundo en cuanto conjunto de fuerzas que se oponen a Dios ${ }^{60}$, pero en ningún modo romper todos los lazos con la realidad exterior y mucho menos con las personas. Aunque restringidas, se mantenían las relaciones interpersonales con quienes vivían fuera del monasterio.

Aunque el texto se refiera al monasterio de clérigos, del hecho ya teníamos constancia por el sermón 356, en que el Santo permite a las personas piadosas llevar a los siervos de Dios lo que les pareciese oportuno con vistas a su recuperación tras una enfermedad 61 . Constancia teníamos también por el último parágrafo del capítulo cuarto de la Regla. El legislador contemplaba en él la posibilidad de que el siervo de Dios recibiera cartas o regalillos de alguna mujer, hecho que acepta, siempre que no se hiciese a escondidas. El presente parágrafo lo confirma, pero ahora con referencia a los padres o cualesquiera otras personas vinculadas al siervo de Dios por algún lazo íntimo ${ }^{62}$. En la presentación del texto son los padres y allegados los que muestran su querencia por el siervo de Dios, no el siervo de Dios quien la muestra por ellos. Como en los otros dos casos, esta relación va acompañada de donativos, ahora especificados sólo a medias: alguna prenda de vestir o cualquier otra cosa juzgada necesaria. No es posible pormenorizar más.

Para valorar adecuadamente el texto, hay que tener en cuenta que el legislador no se propone reglamentar el tipo de relación que ha de mantener el siervo de Dios con sus padres y allegados. Los datos que aporta están seleccionados en función del argumento del capítulo. Sin duda la realidad era más diversificada de lo que resulta del texto. Por ejemplo, no hay que pensar que la relación se redujese al simple ofrecer donativos por parte de unos y recibirlos por parte de otros. Tal proceder se explica fácilmente en el contexto de los siervos de Dios de clase acomodada, pero no siempre sería posible en el caso de los demás. En esta otrá situación habría que pensar más bien en el proceso inverso: que fuese el siervo de Dios, es

59. Cf. respectivamente, praec. 5,2, 1. 153-154 y 2,2, 1. 37-40.

60. Cf. s. $222 ; 313$ A,2; 342,3; ep. Io. tr. 5,9.

61. Cf. $s .356,13$.

62. La expresión es aliqua necessitudine ad se pertinentibus. 
decir, la comunidad monástica, la que hiciese la donación y los familiares quienes la recibiesen. No tiene nada de extraño, habida cuenta de lo que sabemos del mismo san Agustín. Según su biógrafo san Posidio, trató con atención a sus parientes, fueran monjes o no; y, si era necesario, de lo sobrante los proveía como a los demás, no para enriquecerlos, sino para que no padeciesen necesidad, o para aliviarla 63 .

\subsection{Parágrafo cuarto}

Este parágrafo introduce un aspecto nuevo en relación con la ropa: el de su lavado. En cuanto a la ropa en sí, hay que anotar el empleo del término indumentum, frente a uestis/uestimentum a que recurre habitualmente en la Regla ${ }^{64}$. A ambos términos hay que asignarles un valor genérico, fundamentalmente idéntico ${ }^{65}$, y el empleo de uno u otro quizá se deba al deseo de introducir la oportuna uariatio 66.

Por lo que respecta al lavado de la ropa, el interés del legislador no se centra en el hecho en sí sino en quiénes han de llevarlo a cabo. La necesidad de lavar la ropa no se discutía en el monasterio. Sus moradores formaban parte de la sociedad del imperio romano, tan familiarizado con el agua en sus múltiples usos. El texto habla explícitamente de una preocupación excesiva por llevar limpia la ropa ${ }^{67}$. Por otra parte, la vida cenobítica no es compatible con las actitudes que se dieron en el anacoretismo 68. El problema se planteaba, por tanto, respecto a quiénes debían encargarse de la tarea. El texto deja en manos del prepósito optar por una u otra de las dos posibilidades contempladas: los mismos siervos de Dios o (los) lavanderos ${ }^{69}$. ¿Ha de entenderse esto como una alternativa entre lavarla dentro del

63. "Nec suos consanguineos, vel in proposito vel extra constitutos, in sua vita et morte vulgi more tractavit. Quibus dum adhuc superesset, id si opus fuit, quod et ceteris, erogavit, non ut divitias haberent, sed ut aut non aut minus egerent" (Vita Augustini, 31).

64. "aliquid... uestimentorum" (praec. 3,4, 1.59); "Vestes uestras" (5,1, 1. 139); "aliquam uestem" (5,3, 1. 163); "mundae uestis" $(5,4,1.168)$; "siue qui uestibus" $(5,9,1.186)$; "uestimenta uero..." $(5,11,1.190)$.

65. Cf., por ejemplo, s. Dom. m. 1,19,60. Pero, aun siendo un término genérico, indumentum puede ser menos amplio que uestis. De hecho san Agustín distingue el indumentum del operimentum, ambos términos cubiertos por vestimentum: "An quia dixerat, Induit maledictionem sicut vestimentum, differt ab eo vestimentum quo non induitur, sed operitur? Induitur enim quisque tunica, operitur pallio" (en. Ps. 108,21).

66. Téngase en cuenta que poco después en el mismo parágrafo habla de uestis para referirse a lo mismo. Para otra interpretación, cf. AGATHA MARY, 230.

67. “... mundae uestis nimius appetitus” (praec. 5,4, 1. 168).

68. De san Hilarión dice san Jerónimo que jamás lavó su cilicio (vestido de piel de cabra) (Vita Hilarionis, 4).

69. "siue a uobis, siue a fullonibus" (praec. 5,4,1.167). 
monasterio o darla a lavar fuera, o lo que es lo mismo, entre lavarla los siervos de Dios y darla a lavar a "profesionales" ajenos al monasterio? ${ }^{70}$. Es posible que esta interpretación sea la correcta, pero en todo caso no es la única forma de entender el texto. En parte dependerá del significado concreto que se dé al término con que se designa a los lavanderos: fullones. Puede entenderse como referido a cualquier persona que lava o a quienes empleaban determinada técnica de lavado ${ }^{71}$. En este último caso, hay que pensar en unas instalaciones especiales que posiblemente no existían en el monasterio, lo que hacía necesario mandar las prendas fuera. ¿Pero todas? Quizá sólo algunas que requerían un cuidado especial.

Tenemos, pues, una segunda forma de interpretar el texto. La alternativa obedecería a una distinción entre prendas y prendas: unas podrían ser lavadas dentro y, otras, debido a sus condiciones particulares, podrían ser enviadas a lavar fuera del monasterio ${ }^{72}$. En este caso, determinar si una prenda había de ser enviada a lavar fuera, sería competencia del prepósito.

Cabe todavía otra interpretación. Según ella, lo que el legislador deja al criterio del prepósito sería el determinar si, siempre dentro del monasterio, cada siervo de Dios ha de lavar su propia ropa o si toda ha de ser lavada por quienes ejercen el servicio de lavanderos. El conjunto del parágrafo parece favorecer esta última interpretación. La mención del deseo excesivo de llevar la ropa limpia parece indicar que algunos se pasaban el tiempo lavando su ropa, quizá en perjuicio de otras tareas que redundaban más directamente en beneficio de la comunidad. De ahí que el legislador contemple la posibilidad de que el prepósito confíe la tarea a determinados siervos de Dios.

70. En el hecho de que la ropa pueda lavarla gente de fuera, A. de Vogüé ve una manifestación de otra dependencia de la comunidad naciente, destinataria de la Regla, respecto de la comunidad urbana en que se encuentra (DE VOGÜÉ, 3,194).

71. A propósito de esa técnica de lavado leemos: "Los vestidos que se habían de limpiar eran apisonados en hornos, cavea viminea, que se llenaban con agua caliente mezclada con sustancias que separaban la grasa, como nitro, galactita, etc. Para dar al vestido un aspecto bien conservado, se golpeaba primero con varas, después se lavaba, aclaraba, secaba y se cardaba con el cardo fullonicus, se fumigaba con azufre, y finalmente se cepillaba y prensaba con el pressorium. La galactita contribuía a que el vestido se conservara limpio durante un buen espacio de tiempo y devolvía a los colores la brillantez e intensidad que el azufre les había quitado" (Diccionario del mundo clásico, Madrid 1954, 1, p. 743.). Cf. También José GuILlÉn, Urbs Roma. Vida y costumbres de los romanos. I. La vida privada, Salamanca 1977, p. 269.

72. Agatha Mary contempla la posibilidad de que las piezas pequeñas fueran lavadas por los hermanos, mientras que de las piezas más grandes se ocuparan los lavanderos. Otra hipótesis es que la discusión versase sobre qué se mandaba y qué no (AGATHA MARY, 230). 


\subsection{Parágrafo quinto}

Del lavado de la ropa, el legislador pasa a regular las visitas a los baños por parte de los siervos de Dios. Los datos que aporta no dejan de tener interés para el historiador del monacato ${ }^{73}$.

Lo primero que el texto nos hace saber es que los siervos de Dios podían frecuentar los baños. En líneas generales, ello significaba tomar una postura contraria a la de la tradición monástica que no veía con buenos ojos el baño del cuerpo. La prevención frente al mismo provenía, en unos casos, de concepciones ascéticas ${ }^{74}$; en otros, de consideraciones morales. En efecto, es natural que una ascética que busca negar al cuerpo cualquier satisfacción le niegue también el placer del baño; a su vez, la consideración de las circunstancias en que se desarrollaban los baños podía retraer de frecuentarlos a muchas personas, aun sin ser demasiado escrupulosas. Por otra parte, esa resistencia frente a los baños se deja entrever en el mismo texto de la Regla. De un lado, el legislador no lo ordena positivamente, limitándose a indicar que no se deniegue el asistir a ellos y concediéndolo únicamente a quienes se hallen débiles ${ }^{75}$ y sólo bajo prescripción médica; de otro, al menos algunos posibles usuarios tampoco parecen sentirse entusiasmados ante la posibilidad que se les ofrece. Prueba de ello es la orden de obedecer sin rechistar, en el caso de que el médico los ordene. También es cierto, por otra parte, que a otros siervos de Dios les apasionaban. El legislador habla, al respecto, de cupiditas. La causa que subyace a esa diferente actitud frente al baño no es fácil determinarla. Una explicación puede hallarse en el ámbito psicológico. Hay personas que creen saber mejor que nadie lo que conviene a su salud y se aplican sus propias recetas. Es gente que suele rehusar ponerse en manos de los médicos. Para los rea-

73. No es este el lugar para hablar de lo que significaban los baños en la sociedad romana, ni para hablar de sus modalidades ni instalaciones. Cf. al respecto J. JÜTHNER, Bad, en RealLexikon für Antike und Christentum 1 (1950) 1134-1143. Para los datos que nos aporta san Agustín, puede lerse A. ZumKeller, Balneum, balneae, en Augustinus Lexikon 1, 569573.

74. Cf. L. VerheIJEn, Éléments d'un Commentaire de la Règle de saint Augustin. XVI. "Non pas à moins de deux ou trois", en Augustiniana 32 (1982) 255-262: 255 NA 2, 166-173: 166.

75. “... cuius infirmitatis necessitas cogit” (praec. 5,5, 1. 169). Cf. J. A. ONTALBA RuIPÉREZ, El baño, el lecho y el hábito en las Reglas monásticas visigodas del s. VII y en sus fuentes, en Monjes y monasterios españoles. III. Bibliotecas, Archivos y Escritorios, Historiografía y Bibliografía, Documentación, Vida cotidiana, religiosa, material y cultural, Jurisdicción, Museos, Hospitalidad, Misiones. Instituto Escurialense de investigaciones históricas y artísticas, San Lorenzo de El Escorial 1995, 802ss. 
cios, se pueden añadir las motivaciones de tipo ascético o moral indicadas antes; para los no sólo dispuestos, sino hasta deseosos, cabe aducir una costumbre placentera para ellos, arraigada desde antes de ingresar en el monasterio ${ }^{76}$.

El presente parágrafo deja al legislador en cierta medida fuera de la tradición monástica en general, pero no lo ubica plenamente dentro de la tradición romana. Se mantiene dentro de esta última al permitir los baños por motivos terapéuticos ${ }^{77}$, pero se aleja de ella al renunciar al baño por motivos higiénicos, sociales 78 o de simple placer, algo por otra parte muy comprensible en el autor de una Regla monástica.

De puertas adentro, el parágrafo refleja muchas tensiones internas ${ }^{79}$.

\subsection{Parágrafo sexto}

$\mathrm{Al}$ ámbito histórico pertenece también la figura del médico. El capítulo quinto es el único que lo menciona, y dos veces. Su mención explícita no aparece hasta el presente parágrafo ${ }^{80}$, aunque ya fue aludido indirectamente en el parágrafo anterior al hablar de la "medicina". Detrás del término abstracto, había que entender sin duda, a un médico de carne y hueso ${ }^{81}$.

76. El placer estaba detrás del deseo de algunos siervos de Dios de frecuentar los baños. El texto no deja lugar a duda: "Aliquando enim, etiam si noceat, prodesse creditur quod delectat" (praec. 5,5, 1. 173-174); "quod delectat expediat” (ib. 5,6, 1. 177).

77. En realidad, en la Regla, el legislador no asigna a los baños un valor propiamente terapéutico o curativo. De hecho, no los prescribe para los enfermos, sino para quienes se hallan débiles, se supone que en período de convalecencia. A este respecto, L. Verheijen señala cuán lógica es la postura de la Regla. Sólo los permite a quienes están débiles, á quienes anteriormente (cf. praec. 3,1.3) ha dispensado del ayuno. En efecto, "les bains dans les thermes rendaient une restauration adéquate indispensable. Dans les monastères, la "table des pauvres" étant le régime normal, une visite aux thermes ne pouvait être qu'exceptionelle" (Les sermons de saint Augustin pour la carême (205-211) et sa motivation de la vie "ascetique”, en Augustiniana 21 [1971] 358-404: 379, n. 60 NA 1, 153-200: 175). Como prueba aduce la ep. 55,6,9 en que explica por qué los candidatos al bautismo, y con ellos muchos fieles, no ayunaban el Jueves Santo: en esa fecha iban a los baños y no podían soportar al mismo tiempo el ayuno y el baño $(i b$.). Pero, por esto mismo, también podría hablarse de cierta falta de lógica, dado que el baño se concede sólo a los débiles.

78. Cf. Agatha Mary, 234.

79. AgAtha MARY, 233.

80. "sed tamen, utrum sanando illi dolori, quod delectat expediat, si non est certum, medicus consulatur" (praec. 5,6, 1. 176-178).

81. “... sed fiat sine murmure de consilio medicinae" (praec. 5,5, 1. 170). “... il est évident... que dans la Règle, il s'agit moins de la science médicale en général (ars medicinae ou medicina) que d'un praticien en chair et en os" (L. VERHEIJEN, "Sur ordenance de la 'faculté" [De consilio medicinae]", en Augustiniana 23 [1973] 328-333: 331 NA 1,374-379: 377). 
El monasterio tenía, pues, a su disposición un médico. Nada extraño, dada la importancia que san Agustín otorga a la salud de los siervos de Dios, como resulta sobre todo del capítulo tercero de la Regla. Cabría preguntarse si el médico era un miembro del monasterio o un "profesional" ajeno al mismo, cuyos servicios se solicitaban cuando la necesidad lo requería. En principio no cabría excluir la posibilidad de que un médico se convirtiese en siervo de Dios; pero se trataría de un hecho puntual que no siempre se daría. Por ello, lo lógico es pensar en la segunda posibilidad. La indicación explícita de que se debe consultar al médico quizá incluya el sentido preciso de salir fuera del monasterio e ir a su "consulta". Salida del monasterio que estaría incluida en la indicación genérica del parágrafo siguiente: "a cualquier otro lugar adonde hubiera que ir".

\subsection{Parágrafo séptimo}

Las salidas fuera del monasterio fueron mencionadas ya en dos parágrafos del capítulo cuarto de la Regla ${ }^{82}$. El presente parágrafo vuelve a ocuparse de ellas. El legislador procede como en el parágrafo sexto del capítulo cuarto: tras señalar un destino concreto, allí la Iglesia, aquí los baños, alude a otros posibles: allí, cualquier lugar donde hubiere mujeres; aquí, cualquier lugar a donde hubiera necesidad de ir.

El destino concreto que señala el parágrafo es el de los "baños" 83 . El término utilizado, balneas ${ }^{84}$, puede indicar tanto los lugares de baño públi$\cos$, construidos con frecuencia por ciudadanos ricos y poderosos 85 , como lugares de baño existentes en casas o villas particulares ${ }^{86}$. Los comentaristas suelen inclinarse por los baños públicos ${ }^{87}$, aunque no todos. L. Cille-

82. Cf. praec. 4,2.6.

83. Del hecho de que el legislador vuelve a referirse a los baños en este parágrafo, Agatha Mary deduce que era un tema candente entre los hermanos (cf. AGATHA MARY, 239). No nos resulta convinciente el argumento.

84. En las Confessiones san Agustín se refiere a su etimología con estas palabras: “... había oído que el nombre de baño (balneo) venía de los griegos, quienes lo llamaron balanion por creer que arrojaba del alma la tristeza" (conf. 9,12,32). El Santo sólo usa dos veces el término termas (thermae): una vez como simple designación de un lugar (Breuic. 1,14) y otra como lugar de inmoralidad (prurigo thermarum: cat. rud. 16,25). Cf. A. ZUMKELLER, Balneum, balneae, en Augustinus Lexikon 1, 569-573.

85. Así cabe entender los baños de Sosio (cf. c. Fort. prol.), en que se celebró el debate del aún presbítero Agustín con el también presbítero maniqueo Fortunato, dado que tuvo lugar "en presencia del pueblo".

86. Por ejemplo, los existentes en Casiciaco (cf. beata u. 4,23; ord. 1,8,25; etc.).

87. Sage, 246; van Bavel 72; Boff 150; Agatha Mary 234; De Vogüé 3,194. 
ruelo cree que el parágrafo habla de baños medicinales, lo que explica el recurso a la prescripción facultativa y que estén asociados a la enfermedad. Anota que algunas denominaciones toponímicas del norte de Africa hablan de "aguas" y añade que, además de dos grupos de termas ya excavados, se ha descubierto una gran fuente que probablemente se usaba para baños medicinales ${ }^{88}$. Es difícil determinar si se trataba de baños públicos o privados. ¿Cabría pensar que alguna familia pudiente hubiese puesto a disposición del monasterio sus instalaciones? No es de descartar, pero no hay prueba alguna. El hecho de que hayan de ir siempre acompañados ${ }^{89}$ no desequilibra la balanza ni a favor de una opción ni de otra.

En cualquier caso, el texto indica al historiador la falta de autarquía del monasterio al respecto, así como una relativa proximidad de los recursos de la ciudad 90 .

El parágrafo se refiere genéricamente a otros lugares a donde, dado el caso, hubiera necesidad de ir. ¿En qué lugares o circunstancias piensa el legislador? Aquí habría que descartar la Iglesia, porque a ella iría el conjunto de los siervos de Dios. No cabe pensar en que salieran a ella por motivo de oración privada, dado que para ese menester disponían del oratorio dentro el monasterio. Ateniéndonos a las indicaciones de la Regla, podemos suponer que salieran a llevar la ropa a los lavanderos ${ }^{91}$, a vender los productos del trabajo de la comunidad ${ }^{92}$, a la consulta al médico ${ }^{93}$, etc.

$\mathrm{Al}$ ordenar que los siervos de Dios no salgan del monasterio solos, san Agustín no introduce ninguna novedad. La norma ya se encuentra en san Pacomio ${ }^{94}$ y en el Ordo Monasterii ${ }^{95}$. Lo único específico de la Regla se

88. Cilleruelo, Comentario 414. A su parecer, la presencia de monjes en los baños públicos llamaría demasiado la atención, sobre todo si iban en grupo ( $i b$.). No creemos que haga falta pensar en baños específicamente medicinales, puesto que el valor terapéutico del baño era generalmente admitido; además, como ya indicamos, san Agustín no concede el baño a los propiamente enfermos, sino a quienes se hallan débiles.

89. .Nec eant... minus quam duo uel tres" (praec. 5,6, 1. 179-180).

90. De VoGÜÉ, 3,194. El autor establece la comparación con la Regla de san Benito, en la que parece que los baños tienen lugar a domicilio, como también en la legislación de san Pacomio y san Columbano (ib. n. 273).

91. Cf. praec. 5,4. Según alguna de las hipótesis de interpretación antes señaladas.

92. Cf. praec. 5,2, que habla de las distintas actividades (opera) y también, como paralelo, Ordo Monasterii 8.

93. Cf. praec. 5,5 .

94. "Nessuno sia mandato fuori da solo per qualque affare, senza che gli sia dato un compagno" (praec. 56; cf. G. TuRBESsI, Regole monastiche antiche, Roma 1974, p. 114).

95. "Si opus fuerit ad aliquam necessitatem monasterii mitti, duo eant" (ordo monasterii 8). 
refiere al número: habla de uno o dos acompañantes, mientras los textos monásticos aludidos reclaman sólo uno.

\subsection{Parágrafo octavo}

El único dato nuevo que aporta este parágrafo para la historia del monacato es la existencia en el monasterio del oficio de "enfermero" 96. Del texto se puede deducir que es competencia suya determinar la dieta apropiada para cada paciente. De hecho, el legislador no sólo le confía el tomar de la despensa lo necesario para cada uno, sino también el determinarlo ${ }^{97}$. Habida cuenta que esta función parece requerir cierta cualificación, sorprende que no ponga condición ninguna a la persona que haya de desempeñar el cargo y recurra a una forma muy genérica: a uno cualquiera (uni alicui).

\subsection{Parágrafo noveno}

Para su buena marcha, el monasterio necesita determinados oficios. El presente capítulo menciona varios de ellos ${ }^{98}$. Hemos visto aparecer ya a los encargados de la custodia de la ropa de vestir, a los enfermeros y quizá también a los lavanderos; el presente parágrafo añade a los encargados de la despensa, de la ropa de vestir y de los libros ${ }^{99}$. Esta información invita a algunas consideraciones. En primer lugar, cabe preguntarse si el plural utilizado se refiere a cada uno de los oficios o, al contrario, responde a la consideración global de todos. En el primer supuesto, tendríamos una indicación indirecta de que el número de siervos de Dios del monasterio no era reducido, ya sea porque para cada oficio se requería más de uno, ya porque contaba con personal suficiente para confiar a varios una misma tarea.

En segundo lugar, la mención del oficio relacionado con la ropa plantea la cuestión de si se trata del mismo mencionado en el parágrafo prime-

96. La Regla se ha ocupado ya con anterioridad de la atención a los convalecientes, pero sin indicar que ese cuidado estuviese confiado a nadie en concreto: "... post aegritudinem sic tractandi sunt, ut citius recreentur" (praec. 3,5, 1. 69-70). 185).

97. "... ut ipse de cellario petat, quod cuique opus esse perspexerit" (praec. 5,8, 1. 184-

98. Hay que destacar la diferencia entre el capítulo tercero de la Regla y el presente. En aquel señalaba determinadas acciones (dar un plus de alimento, prendas de vestir o ropa de cama, a los que por su condición especial las necesitaban), pero no quiénes debían ejecutarlas en nombre de la comunidad; en el presente, en cambio, en el centro de la atención del legislador aparecen ya los encargados de ejecutar esas $u$ otras acciones.

99. "Siue autem qui cellario, siue qui uestibus, siue qui codicibus praeponuntur..." (praec. 5,9, 1. 186-187). 
ro. La razón es que uno y otro oficio tienen en común el ocuparse de la ropa de vestir, pero en cada texto se les asigna una función distinta: según el parágrafo primero, tarea de los que lo desempeñan es atender a su conservación; según este parágrafo noveno, es competencia suya servirla a los hermanos. La lógica pide pensar en un único oficio. Lo contrario podría convertirse en fuente de reiterados conflictos. La diversidad de función que tiene asignada en los distintos parágrafos quizá hay que atribuirla a que en cada caso el legislador mira a un objetivo distinto: en el parágrafo primero, a eliminar el sentido de propiedad en quien usa la ropa; en el noveno, a eliminar ese mismo sentido de propiedad en quien la tiene confiada a su cuidado. No hay que excluir que se deba a una simple variatio retórica 100.

Por último, el hecho de que exista el oficio de bibliotecario merece ser considerado con un poco más de detenimiento. De los tres oficios señalados en el presente parágrafo es aquel al que los comentaristas de la Regla prestan más atención. Ahora no nos ocupamos del oficio de bibliotecario, sino de la existencia de la biblioteca misma. Nada más normal en un monasterio con san Agustín como fundador. Es lo que cabía esperar de quien pasó toda su vida entre libros, siendo, además de ávido lector, prolífico autor; de quien asoció la condición de siervo de Dios con la búsqueda de la sabiduría; de quien, pensando en los venideros, mandaba que se guardasen con esmero la biblioteca de la Iglesia y los códices 101; de quien dejó a la Iglesia, como único legado, clero más que suficiente, junto con monasterios poblados de siervos y siervas de Dios, cada uno con su biblioteca provista de libros y "tratados" compuestos por él o por otros "santos" 102.

$\mathrm{Al}$ interesado en el monacato agustiniano de los orígenes le gustaría saber qué clase de libros contenían las bibliotecas monásticas. De entrada hay que dar por cierto que disponían de los libros de la Sagrada Escritura. No contamos con una afirmación explícita en la Regla al respecto, pero lo contrario sería de todo punto impensable. Además existen indicaciones indirectas, como la que ofrece la obra El trabajo de los monjes. En el ori-

100. Basta advertir el sucederse de los modos de designación: “... uno custode... sub communibus custodibus" (praec. 1,5); "... qui uestibus praeponuntur" (ib. 5,9); "... sub quorum custodia..." (ib. 5,11).

101. "Ecclesiae bibliothecam omnesque codices diligenter posteris custodiendos semper iubebat" (Posidıo, Vita Augustini, 31). La mención por separado de los "códices" se debe muy probablemente a que con dicho término indica los libros litúrgicos, que estarían en un lugar que facilitase su uso en el culto, y no en la biblioteca.

102. "Clerum suficientissimum, et monasteria virorum ac feminarum continentibus cum suis praepositis plena Ecclesiae dimisit, una cum bibliotheca et libris tractatus vel suos vel aliorum sanctorum habentibus..." (Posidio, Vita Augustini, 31). 
gen de la obra está el hecho de que determinados monjes rehusaban entregarse al trabajo manual para poder dedicarse íntegramente a la oración, a la salmodia, a la lectura de la palabra de Dios ${ }^{103}$. Tales monjes no podrían proponer esta actividad alternativa al trabajo manual de no contar con los instrumentos para realizarla, esto es, los Libros Sagrados.

El texto sobre el legado de Agustín que acabamos de citar ofrece una referencia clara, aunque genérica, sobre otros libros que existían en las bibliotecas monásticas. El texto en sí podría no tener mucho valor aplicado a la comunidad específica a que fue dirigida la Regla. San Posidio escribe tras la muerte de san Agustín, muchos años después de compuesta la Regla y, además, lo indicado puede responder más a una suposición lógica que a un conocimiento preciso: parece obvio que en la biblioteca del monasterio del que el Santo formaba parte se hallasen sus propios libros y "tratados" 104. Obvio también, que tuviese escritos de otros autores. Dos hechos concretos llevan a esa conclusión. Uno, que, ordenado presbítero inesperadamente, sintió la necesidad de adquirir una formación teológica y sobre todo bíblica de las que carecía, para poder ejercer en la forma debida el ministerio; y esa necesidad motivó el viaje del amigo Alipio a Tierra Santa, para encontrarse con san Jerónimo ${ }^{105}$. Otro, la constatación de que ha leído tratados teológicos de otros autores cuyo nombre no nos ha trasmitido 106. Determinar en concreto de qué obras se trataba es ya más difícil 107.

Por otra parte, habría que saber si los libros de que dispuso el Santo se hallaban en la biblioteca de la Iglesia o en la del monasterio. Y en este último caso, si cuando él trasladó su residencia al monasterio de clérigos, llevó consigo tales libros o los dejó allí. Parece lógico admitir que el Santo no se fue sin ellos, puesto que tan necesarios le eran para su ministerio y activi-

103. El texto distingue entre "lectura" y dedicarse a "la palabra de Dios"; pero como apunta L. Verheijen, se trata sin duda de una endíadis. Cf. Eléments d'um Commentaire de la Règle de saint Augustin. XVII. "Les livres", en Augustiniana 32 (1982) 262-265: 265 (?) NA 2, 174-177: 177.

104. En general, en el lenguaje de san Agustín bajo "tratado" hay que entender una predicación exegética, que mira más a la enseñanza que a la edificación. Cf. C. MoHRMANN, "Praedicare, tractare, sermo", en Études sur le latin des chrétiens, Roma 1961, II, 70-71; G. BARDY, "Tractare, tractatus", en Recherches de Science Religieuse (1946) 211-235.

105. Cf. ep. 28,1.4; 39,2,2 (= JERONIMO, 103,2,2).

106. Cf. f. et Symb. 9,19-20.

107. La ignorancia se extiende al número de códices, si eran parte de las posesiones del siervo de Dios, puestos en común al entrar en el monasterio, si procedían de regalos, si tenían por autores a algún miembro de la comunidad, fuera de san Agustín, si fueron copiados dentro, etc. (cf. AgATHA MARy, 248). El estudio más amplio sobre la biblioteca de Hipona es J. SCHEELE, Buch and Bibliothek bei Augustinus, en Bibliothek und Wissenschaft 12 (1978) 14-114, esp. p. 42-54, del que no hemos podido disponer. 
dad intelectual. Pero también parece lógico pensar que, en ese caso, dejara una copia al menos de sus propios escritos en el monasterio.

El parágrafo todavía aporta algún otro dato de interés sobre los libros. En la antigüedad los libros - ahora los contemplamos en su materialidad - variaban de unos a otros o por el material de que estaban compuestos o por la forma que adquirían. El material podría ser pergamino o papiro; en cuanto a la forma podía tener la del volumen o rollo, o la del codex. El parágrafo no nos indica directamente nada acerca del material de los libros de la biblioteca monástica; en cambio, habla explícitamente de codex. Esta era, en efecto, la forma de libro preferida por los cristianos ya desde muy pronto. Las razones eran sobre todo prácticas 108.

\subsection{Parágrafo décimo}

En el presente parágrafo los libros se convierten en el centro de atención. El texto nos aporta datos de interés tanto sobre el monasterio y la vida en él como sobre sus moradores. En síntesis, deja entender que en el horario de la comunidad había un espacio específico para la lectura, que la lectura era cultivada con esmero y, en consecuencia, que los siervos de Dios no eran analfabetos. Veamos más de cerca cada uno de estos datos.

En el parágrafo se ordena que los libros se pidan cada día a una hora determinada ${ }^{109}$. La pregunta surge: cuando los siervos de Dios pedían un libro, ¿dónde lo leían? ¿En la misma biblioteca? Entonces se explicaría que no se diesen a quien los pidiese fuera de hora. ¿En otro lugar? ${ }^{110}$. En este caso hay que pensar en un espacio del monasterio que sirviese como lugar de lectura, aunque pudiese servir también para otros usos.

Esta "hora determinada" es indicación bastante clara de la existencia de un horario "de biblioteca"; el "cada día" no deja duda de que tal horario no era de carácter mensual, ni semanal, sino diario. El contacto con los libros era, pues, una auténtica actividad en la vida de los siervos de Dios,

108. Cf. Harry Y. GAmble, Books and Readers in the early Church. A History of Early Christian Texts, Michigan 1995, p. 42-81. "But if not every early Christian text was written in a codex, it would not contravene the evidence of the papyri that the codex was the heavily preferred form of the early Christian book well in advence of its broad adoption outside Christianity" (ib. p. 81).

109. "Codices certa hora singulis diebus petantur; extra horan qui petierit, non accipiat" (praec. 5,10, 1. 188-189). Algo similar, pero más concreto, prescribe el ordo monasterii 3: “... et ad nonam reddant codices..."

110. No falta quien interpreta el "pedir" como licencia para "sacar" libros de la biblioteca (cf.¿ZuMKELler, 103). 
no una ocupación de relleno para cuando no tenían otra cosa que hacer, ni de "fin de semana", en plan de descanso o entretenimiento. Los detalles de ese horario lamentablemente nos son desconocidos. A un horario monástico, pero sin definirlo exactamente, hace referencia san Agustín en la obra El trabajo de los monjes, cuando indica lo que eran sus anhelos, cuya realización le resultaba imposible debido a las exigencias del ministerio pastoral: “...preferiría mil veces ocuparme en un trabajo manual a diario y a horas determinadas, como se halla establecido en los monasterios bien organizados, y disponer libremente de las restantes horas para la lectura y la oración, o para ocuparme de la Sagrada Escritura" 111.

A pesar de su indiscutible interés, este texto no nos permite conocer qué parte del día estaba dedicado a la lectura, ni cuántas horas. Una indicación, sin embargo, lo podemos obtener del Ordo monasterii. Esta breve Regla monástica africana ordena lo siguiente: "Dedíquense al trabajo manual desde por la mañana hasta la hora de sexta, y desde la hora de sexta hasta la de nona ocúpense en la lectura. A la hora de nona, devuelvan los libros" 112. Tres horas, pues, diarias dedicaban a la lectura los usuarios de esta Regla monástica. Un tiempo considerable. Más que el dato en sí, llama la atención, sin embargo, el momento del día que se le reservaba: de la hora sexta a la hora nona, es decir, de las doce del mediodía hasta las tres de la tarde, hora en que tenía lugar la comida. La lógica de tal horario se puede resumir en estos términos: después del trabajo manual, el trabajo intelectual 113; antes de alimentar el cuerpo, alimentar el espíritu ${ }^{114}$. Teniendo en cuenta que en los días de ayuno, que eran muy frecuentes, no probaban bocado hasta la comida, las horas dedicadas a la lectura eran aquellas en que "el detenerse de toda digestión pone al cuerpo alerta, al espíritu apaciguado y lúcido". Era, por tanto, "el tiempo óptimo para toda

111. "... multo mallem per singulos dies certis horis, quantum in bene moderatis monasteriis constitutum est, aliquid manibus operari, et caeteras horas habere ad legendum et orandum, aut aliquid de divinis Litteris agendum liberas..." (op. mon. 29,37). Nótese la identidad de términos entre este texto (per singulos dies certis horis) y el texto del parágrafo que nos ocupa (certa hora singulis diebus). Sobre el significado de aliquid de divinis Litteris agendum, cf. L. VERHEIJEN, Saint Augustin, un moine devenu prêtre et évêque, en Estudio Agustiniano 12 (1977) 281-334: 296 N.A 1, 251-299: 265.

112. "Operentur a mane usque ad sextam, et a sexta usque ad nonam uacent lectiớni, et ad nonam reddant codices" (ordo mon. 3 ).

113. El trabajo manual continuaba después de la comida: “... postquam refecerint,... faciant opus usque ad horam lucernarii" ( $i b$.$) .$

114. Este alimentar el espíritu continuaba, como en la Regla, durante la refección material: "Sedentes ad mensam taceant, audientes lectionem" (ordo mon. 7). 
especie de actividad, especialmente para la lectura" 115 . No se puede demostrar, pero tampoco cabe excluirlo de entrada, que el horario del monasterio destinatario de la Regla, fuese el mismo que el señalado 116.

La prohibición de dar libros a quienes los pidan fuera de la hora puęde deberse a que en ningún grupo humano faltan personas que, por simple despiste, se olvidan de hacer las cosas cuando deben hacerlas. Pero puede explicarse también desde la conjunción de dos circunstancias: una, la existencia de personas amantes de los libros, para las que todo el tiempo de lectura es poco y aprovechan cualquier momento para ese fin; otra, el disponer de tiempo libre. Esto sería posible si el trabajo manual estuviera organizado en función de las tareas, no del tiempo. Si uno concluía la tarea de su competencia antes de que se agotase el tiempo asignado para ella, podía dedicar lo que le sobraba a la lectura. Ahí podría tener su origen lo que prohíbe el legislador en este parágrafo. El hecho no es pura hipótesis. Una situación similar fue contemplada a propósito del parágrafo segundo del capítulo segundo. La diferencia estaría en que allí el legislador aconsejaba indirectamente dedicar ese tiempo sobrante a la oración, mientras que aquí no dejaría emplearlo en la lectura. ¿Cuál podía ser la razón? ¿Porque quería que empleasen ese tiempo en la oración? Es posible, pero cabe otra explicación: no molestar a los otros. En el caso de la oración, esta nueva actividad no requería meter en danza a nadie más; en el caso de la lectura, en cambio, implicaba, al menos, al bibliotecario. Es pura hipótesis, pero creemos que cae dentro de la lógica. De ser cierta esta interpretación, se podría deducir un auténtico interés intelectual al menos en algunos de los siervos de Dios del monasterio.

Todo lo dicho hasta aquí a propósito del parágrafo décimo permite concluir que los siervos de Dios del monasterio destinatario de la Regla no eran, al menos en su mayoría, analfabetos. Si se tiene en cuenta que una buena parte de sus moradores provenía de las clases más humildes, como ya hemos tenido ocasión de constatar ${ }^{117}$, lo lógico es pensar que entraron en el monasterio siendo efectivamente analfabetos. Mas, por otra parte, un

115. A. DE VoGÜÉ, L'horaire de l' Ordo Monasterii. Ses rapports avec le monachisme égyptien, en Homo Spiritalis. Festgabe für Luc Verheijen OSA zu seinem 70. Geburtstag. Herausgegeben von C. Mayer unter Mitwirkung von K. H. Chelius, Würzburg 1987, 240-258: 256257).

116. Según op. mon. 29,37 , el horario de los monasterios bien organizados reservaba un tiempo dedicado al trabajo manual, pero no indica ni de qué ni de cuántas horas se trataba, ni sobre el resto de las ocupaciones del día.

117. Cf. Comentario a la Regla de san Agustín. Capítulo tercero, en Estudio Agustiniano 37 (2002)275-317: 295ss. 
horario monástico que reserva un espacio diario de tiempo para la lectura sería incoherente y abstruso en el caso de que fuesen analfabetos la mayoría de los monjes. En consecuencia, no cabe aplicar estadísticas generales, válidas para el conjunto de la sociedad, a los moradores del monasterio agustiniano ${ }^{118}$. De donde parece legítimo deducir que fue en el monasterio donde aprendieron a leer y que el monasterio se convertía para los analfabetos en una auténtica escuela ${ }^{119}$. El hecho no significaría nada novedoso; otros fundadores monásticos, anteriores al obispo de Hipona, habían puesto particular esmero en capacitar a los monjes para que, al menos, pudieran leer la Escritura 120.

\subsection{Parágrafo undécimo}

Este último parágrafo del capítulo menciona dos oficios: el primero, ya conocido ${ }^{121}$, tiene como tarea cuidar de la ropa; el segundo, aparece por primera vez, y tiene a su cuidado el calzado. Cabe que se trate de uno sólo, sobre todo si el plural obedece a que lo desempeñaban más de una persona.

\section{Interpretación ascético-espiritual}

Fieles al procedimiento seguido en el comentario a otros capítulos, en la presente sección quitamos a san Agustín el protagonismo para otorgarlo a sus comentadores. Nos limitamos a recoger, de forma sumaria, los aspectos que han subrayado y la interpretación que han dado, referido todo únicamente al ámbito ascético-espiritual.

118. Según Harry Y. Gamble (Books and Readers in the early Church. A History of Early Christian Texts, Michigan 1995, p. 10.231), el porcentaje de cristianos capacitados para leer fue siempre una minoría y probablemente nunca superó el 15-20\%.

119. El mismo san Agustín da por hecho esa formación en el monasterio de Cartago: "Et si qui sunt inter eos, qui eo proposito ad sanctam militiam venerint, ut placeant cui se probaverunt $(2 \operatorname{Tim} 2,4)$, cum ita vigeant viribus corporis et integritate valetudinis, et non solum erudiri, sed etiam secundum Apostolum operari possint..." (op. mon. 22,26). "Illiterate monks and nuns must have been the exception. Anyone unable to read at the time of entrance was evidently taught to do so inmediately" (ZUMKELLER, 103).

120. Por ejemplo, san Pacomio prescribió que se enseñase a leer a todos los postulantes (Praecepta, 130-140). Lo mismo san Basilio. Es él quien escribe en las Regulae fusius tractatae, 15: "É necessario che anche lo studio sia conforme al fine che ci siamo proposti, in modo che i ragazzi imparino a servirsi delle parole tratte dalla Scrittura..." (texto trascrito de la edición, BASILIO DE CESAREA, Le Regole. Regulae fusius tractatae. Regulae brevius tractatae. Introduzione, traduzione e note a cura di Lisa Cremaschi. Edizioni Qiqajon. Comunità di Bosé 1993, p. 128).

121. Cf. praec. 5,1, 1. 139-140. 151-152. 


\subsection{Planteamientos generales}

En general, se entiende que el capítulo quinto permite comprender el significado concreto del texto de los Hechos de los Apóstoles (Hech 4,3235) aplicado a las circunstancias de la vida monástica diaria ${ }^{122}$. En el capítulo se ve a san Agustín moverse más cerca del centro de cada hombre, más allá de las características personales y sociales, que en el capítulo primero aparecían como impedimentos a la unidad de almas ${ }^{123}$. Si los cuatro primeros capítulos buscaban construir la unidad entre los hermanos, de ahí que se mencionasen pocas reglas y costumbres, con el capítulo quinto comienza una segunda parte en la que, al ser el amor el rasgo dominante, aparecen más normas. La contradicción es sólo aparente, puesto que las reglas sin amor son tiranía y las reglas que lo expresan aseguran la libertad 124. En efecto, en sus distintos parágrafos el capítulo quinto orquesta el tema del amor en el marco de los asuntos ordinarios del monasterio, mostrando que es precisamente el amor que alcanza a los otros, discerniendo sus necesidades y tratando de aliviarlas, el supremo factor generador de unidad ${ }^{125}$. En él la vida del monasterio aparece estructurada por la caridad que hace de muchas almas una alma sola, trasfigura lo cotidiano y le da valor de eternidad y cualifica hasta las menores acciones de los hermanos 126. En él la vida común es vista como servicio amoroso a los hermanos 127 . Otros autores advierten en el capítulo un tránsito desde el detalle menudo atañente a la propiedad de las cosas hasta la disposición espiritual de la caridad; el contraste entre lo vulgar y lo sublime ${ }^{128}$; el modo como se aplican siempre los dos grandes principios de la comunión de bienes y de la

122. ZUMKELLER, 91.

123. Agatha Mary, 247.

124. Agatha Mary, 212. La autora considera que en los capítulos 5-8 se da una recapitulación de los principales temas de los cuatro primeros capítulos (ib., 213). Algo que no compartimos.

125. Agatha Mary, 251-252.

126. L. VERHEIJEN, La charité ne cherche, NA 2,220. El autor se expresa en estos términos: "L'auteur ne pouvait pas être plus clair: le plus banal élément de la vie de tous les jours a une valeur d'éternité si c'est la charité qui l'anime, cette charité qui dans le plain divin doit dominer la vie dans l'histoire passegère et qui, elle, "ne passe jamais"” (ib.). Cf. también MARIE-ANCILLA, 101.

127. G. LAwLESS, The Rule of saint Augustin as a Mirror of Perfection, en Angelicum 58 (1981) 460-474: 466.

128. C. VACA, La condición humana y la vida común, en Revista Agustiniana de espiritualidad 1 (1960) 53-62: 61. 
distribución proporcional en las cosas cotidianas y simples ${ }^{129}$. La importancia del capítulo radica en mostrar el espíritu que debe animar los servicios prestados a los hermanos y la preferencia del bien común sobre el privado ${ }^{130}$. El tema de la pobreza monástica y la renuncia a la propiedad aparece también como clave de lectura del capítulo ${ }^{131}$.

\subsection{Parágrafo primero}

El acento se pone en el precepto de guardar la ropa en común ${ }^{132}$, lo que se valora como una medida sabia 133. Dado que los siervos de Dios deben habitar in unum, también su ropa ha de ser guardada in unum ${ }^{134}$. Para juzgar las directrices concretas es frecuente tomar como criterio, junto con los intereses de la vida común, la pobreza evangélica ${ }^{135}$. Según otro parecer, lo que el legislador saca a la luz en este parágrafo es la santidad o la actitud del monje hacia sí mismo y hacia sus necesidades 136.

El que comience con la referencia al vestido se atribuye a que el espíritu de propiedad se instala más fácilmente en el corazón a propósito de él, pues se considera un bien personal ${ }^{137}$. Más en general, la envidia y el descontento surgen a menudo en relación con los bienes materiales, que son siempre una amenaza para la auténtica convivencia, al dirigir al hombre hacia sí, sin tener en cuenta a los demás ${ }^{138}$. De ahí que se prescriba que haya una única ropería. Si se confía su cuidado a uno o dos hermanos es para que los demás puedan entregarse al estudio, la oración y el apostolado ${ }^{139}$. De otra parte, se ven aplicados aquí los principios básicos de la Regla: la comunión de bienes (una despensa y una ropería) y la distribución proporcional: a cada uno lo que necesite ${ }^{140}$.

129. BOFF, 139.

130. F. MORIONES, Espiritualidad agustino-recoleta, II, 260).

131. SAGE, 241.

132. ZuMKELler, 92.

133. Agatha Mary, 213. Añade consideraciones sobre cómo pueden reaccionar las personas responsabilizadas de la tarea.

134. MARIE-ANCILLA, 171. "Le vestiaire doit donc être, comme la dépense, l'expression du propos fondamental des serviteurs de Dieu: le rassemblement "en un"” ( $i b$.).

135. Zumkeller, 92; Trape, 162; SAGE, 242-243; BoFF, 140-141;

136. Agatha Mary, 217.

137. SAGE, 242.

138. VAN BAVEL, 74.

139. SAGE, 242. Remite a la indicación de san Posidio de que el Santo se desentendía de los asuntos materiales para aplicarse al servicio de Dios o de las almas (Vita Augustini, 24: cf. también, Cilleruelo, Comentario, 409).

140. BofF, 140. 
La mención de las disputas y las murmuraciones se ve como un indicador del carácter realista de la Regla. Este carácter se manifiesta, de un lado, en la doble constatación de que la ropa de vestir origina fácilmente la tentación de la vanidad y de que las cosas materiales son fuente de conflictos ${ }^{141}$; de otro, en la puntualización "si es posible", que deja ver que no está implicado derecho alguno y que una indiferencia sólida en esta materia es tan rara como la santidad ${ }^{142}$. Se clasifica a las personas: si bien proyectan con sus murmuraciones las propias insuficiencias, tienen realmente necesidades distintas y no sólo por razones climáticas ${ }^{143}$. Se piensa que san Agustín evoca aquí el tema de la confianza en Dios que surge de la pobreza de espíritu: quien sabe que depende en todo de Dios, sabe que lo que recibe es sólo un don, no un derecho ${ }^{144}$. Como falta de espíritu de pobreza se juzgan las disputas y murmuraciones surgidas a propósito de los vestidos, que el Santo trata de eliminar. Se valora como ideal el aceptar prendas diferentes, incluso de inferior calidad, a las llevadas antes ${ }^{145}$. Tales murmuraciones son como el chirriar del engranaje de la comunidad, debido a la falta de lubricante, esto es, un mayor interés por el hábito del corazón y por la belleza del vestido interior, el amor de Dios y del prójimo ${ }^{146}$. En esta referencia al vestido interior se ve una llamada a las verdaderas riquezas, las del espíritu; olvidar estas y litigar por las prendas de vestir es un indicador de una triste miseria ${ }^{147}$. A la vez que se anota la explícita referencia a la santidad, se señala la rara presencia de este concepto en la Regla, dato que se explica porque es siempre un don de Dios, en respuesta al esfuerzo humano; es siempre resultado de algo, no un medio o un fin ${ }^{148}$. Como causa inmediata de los altercados y murmuraciones, se aduce la cali-

141. BOFF, 141.

142. Agatha MARY, 214: "For most people, clothing is an expression of their person, and their attitude to it is an expression of both strength and weakness. In spite of the strong stress on the criterion of need throughout the Rule (cf. 1,3.5; 3.5) and in spite of Augustine's exhortation here that those in the monastery must try to be indifferent about what is given to them to wear, for most members of the group the factor of taste is almost ineradicable since taste itself is an expression of personality" (ib. 215).

143. Agatha Mary, 215-216.

144. Agatha Mary, 215.

145. ZUMKELLER, 91-92.

146. SaGe, 242-243, que remite as. 37,6; también Marie-Ancilla, 172. Boff, 142.

147. TRAPE, 161.

148. Agatha Mary, 217. "By evoking holiness at this moment in his discussion, Augustine deftly shows that absurdity of fussing and fretting about what one wears" ( $i b$. 217). 
dad y la forma variable de las prendas ${ }^{149}$; como causa última, la vanidad o el orgullo y la ostentación 150 .

Se pone de relieve la intransigencia del Santo en cuanto a la custodia en común de la ropa ${ }^{151}$ y sus dudas en cuanto a la propiedad ${ }^{152}$, reflejadas en la tolerancia o benignidad de la Regla, al permitir recuperar los vestidos llevados antes ${ }^{153}$. Algún autor percibe un ritmo decreciente de exigencia 154 , en cuanto que el legislador acaba cediendo a los antojos de los descontentos, en atención a su debilidad, hecho que otro juzga diversamente, esto es, como un nuevo signo de su amplitud de miras, de su respeto por la individualidad y de su sentido de misericordia 155 . Se establece la comparación con los parágrafos tercero, cuarto y quinto del capítulo tercero: si allí avisaba contra la tentación de apegarse a los privilegios, aquí busca reducirlos al máximo ${ }^{156}$. Se sobreentiende que esa tolerancia, prueba del fino olfato psicológico del Santo ${ }^{157}$, es temporal, en tanto que sus beneficiarios son educados poco a poco ${ }^{158}$. También se la justifica para hoy, pero por razones de higiene ${ }^{159}$ y por tratarse de algo extremadamente personal, expresión por otra parte del "yo social" 160 . A la vez se reconoce que lo prescrito sigue siendo el ideal y fuente perenne de inspiración; que se ajusta a las disposiciones del monje que rehúsa toda comodidad superflua y se contenta con lo necesario 161; que lo importante es el espíritu que subyace: el ideal de la comunión de bienes, la exigencia de lo necesario para una vida digna, la búsqueda del hábito interior contra toda tentación de vanidad y la magnanimidad con los límites ascéticos del hermano 162.

También se valora como oportuna la prescripción de cuidar y conservar la ropa ante la tentación del desinterés por las cosas comunes ${ }^{163}$. La

149. MARIE-ANCILLA, 172.

150. Boff, 141. 142; Cilleruelo, Comentario, 409.

151. Zumkeller, 92; Sage, 243; van Bavel, 71; Boff, 142; Marie-Ancilla, 173.

152. DE VoGǗ, 3,192.

153. BOFF, 142.

154. A. de Vogüé habla de un retroceso en relación al Ordo monasterii que prohibía toda propiedad en materia de ropas como en todo lo demás (DE VoGüÉ, 3,192).

155. BOFF, 142.

156. Agatha Mary, 218.

157. Trape, 161; Agtaha Mary, 218.

158. MARIE-ANCILla, 173; De VoGÜÉ, 3,193.

159. SAGE, 243; TraPE, 162; VAN BAVEL, 71; ZuMKELler, 92.

160. BofF, 141. Como razón ulterior, añade que hoy la ropa no es un bien tan raro y escaso como en el mundo antiguo. Cf. también AgATHa MARY, 215; van BAVEL, 71.

161. Trape, 162; SAge, 242.

162. BofF, 142; ZUMKELLER, 92; F. MORIONES, Espiritualidad agustino-recoleta, 2, 260.

163. BOFF, 140 . 
deficiencia en el cuidado de los bienes de la comunidad se juzga como una falta contra la pobreza voluntariamente aceptada 164 .

\subsection{Parágrafo segundo}

El presente parágrafo se lleva la parte del león entre los del capítulo quinto. Con referencia al conjunto de la Regla, sólo le superan en el grado de atención que le prestan los comentaristas los parágrafos primero y segundo del capítulo primero. Recoger la totalidad de las reflexiones que les suscita excedería con mucho el marco de estas páginas. Nos limitaremos, pues, a las ideas centrales.

A propósito de este parágrafo escribe L. Verheijen: "en medio de estos detalles concretos, el autor levanta el vuelo de forma inesperada y formula un pensamiento de alcance universal" ${ }^{165}$. Más en concreto, otro autor indica que el parágrafo aporta la inspiración inmanente de la preocupación de los unos por los otros, la mentalidad que debe caracterizar su concreción, esto es, que, aun en su manifestación inmediata, debe ser expresión de algo que queda a mayor profundidad, relacionado directamente con la espiritualidad comunitaria, pero sin que lo común suplante la responsabilidad personal 166 .

Utilizando una imagen médica, se podría decir que los comentaristas se ocupan mayoritariamente de lo que prescribe el médico, haciendo referencia a la enfermedad, pero suelen pasar por alto el origen de la misma. No así A. Zumkeller, quien se remonta hasta el pecado de origen que pervirtió el correcto amor de sí en que fue creado el hombre ${ }^{167}$, en el sentido

164. Agatha Mary, 213.

165. La charité ne cherche, NA 2,220. Y sigue: "En la qualifiant d"'universelle", je ne pense pas uniquement à la vie dans cette communauté monastique, mais a la vie dans toute son étendue. Saint Augustin précise à cet endroit avec quelle mentalité fondamentale et profonde il fallait, d'après lui, mettre en pratique les prescriptions un peu terre à terre de cet chapitre..." (ib., 220-221). "Il est évident qu'Augustin veut dire par ces paroles quelque chose de capital" (Le Règle de saint Augustin comme prisme... NA 2,62). "Il reste qu'à un moment donné la pensée prend un envol inattendu et qu'Augustin va expliquer dans une brève formule magistrale quel est le rôle de l'amour (de Dieu et des hommes) dans l'usage nécessaire des choses passagères de cette vie. L'importance de cette formule dépasse de loin la cadre monastique qui en est ici le contexte" (La Regle de s. Aug. et l'ethique classique, 7 NA 1,245). Cf. también SAGE, 243: "D'un vigoreux coup d'aile, nous voici transportés à mille lieues au-dessus de nos mesquines préoccupations".

166. VAN BAVEL, 73 .

167. Cf. Trin. $14,14,18$. 
de que lo centró exclusivamente en sí, olvidándose de los demás. Precisamente para combatir ese amor egoísta, el legislador recurre a 1 Cor 13,5: el amor, dice el texto, no busca los propios intereses. Es una realidad que se hace efectiva en el servicio a los hermanos dentro de la comunidad 168 .

Una autora encuentra en el parágrafo la mejor expresión de la solidaridad de la comunidad, anotando cómo no aparece en relación con actos de culto o de testimonio ${ }^{169}$, sino con el compartir las cosas de la vida ordinaria ${ }^{170}$. Pero el valor que se asigna al contenido del parágrafo lo indica el hecho, constante en los comentaristas, de presentarlo como la "regla de oro" 171. Todo se resume en preferir el bien común al particular, principio básico que impregna la estructura espiritual de la Regla ${ }^{172}$. Principio ubicado en la tradición clásica, aunque tenga en la Escritura su base más sólida 173 . Vivir para la comunidad y anteponer el bien común al privado se identifica con el vivir buscando los intereses del Cristo total o vivir para él, siendo, en el fondo, el desarrollo último del primer mandamiento ${ }^{174}$. Este ideal eclesial se complementa con otro social 175.

En este contexto varios autores introducen y desarrollan, con mayor o menor amplitud, la distinción entre el amor privado y el amor social, fun-

168. ZUMKELER, 93-94.

169. Cf. respectivamente, praec. 2,3 y 4,3 .

170. Agatha Mary, 219.

171. Zumkeller, 94; Sage, 243; Manrique-Salas, 188.192; Trape, 140; Cilleruelo, Comentario, 400.401; MARIE-ANCILla, 102; L. VerheiJen, La charité ne cherche, NA 2,220; etc. Como apoyo bíblico se aduce, junto a 1 Cor 13,5, citado en el parágrafo, Fil 2,21; 1 Cor 10,$24 ; 1$ Cor 10,33 , etc.

172. BOFF, 145.

173. Cf. L. Verheijen, La Règle de saint Augustin et l'éhique classique, en Augustiniana 24 (1974) 5-9: 7-9 NA 1, 245-47 con las referencias a los textos clásicos; BofF, 145; MARIEAnCIlla, 104; Cilleruelo, Comentario, 400: "Tanto el platonismo, por su mito del "mundo celeste", como el judaísmo, por su espíritu tribal, reclamaban la subordinación de la zona privada a la zona común. El cristianismo supera ambas concepciones con su doctrina de la Iglesia universal"; DE VoGÜÉ, 3,194 quien comenta: "Identifié à la vertu suprême du christianisme, l'amour du bien comun, dans l'esprit de la meilleure tradition philosophique, est pris pour critère de l'avancement spirituel des moines. On ne peut opter avec plus de décision pour une vision cénobitique du monachisme. Quant à la belle maxime final, qui exalte de nouveau la charité, elle fait penser à un autre sentence d'Augustin, où caritas est remplacé par communia (cf. ep. 243,3). Tant il est vrai que, pour cet esprit pétri de Bible et de philosophie, les deux termes sont interchangeables". Cf. también. G. LAwLESs, The Rule of saint Augustin as a Mirror, 466.

174. Cilleruelo, Comentario, 401, quien añade: "El unum de los neoplatónicos, espiritualizado y personalizado en el un alma sola y un solo corazón de Pentecostés, es el criterio que nunca puede ser superado" $(i b$. $)$.

175. BoFF, 145. 
damental en la doctrina agustiniana ${ }^{176}$, señalando alguno el peligro de sustituir el orgullo individual por el colectivo que es otra forma de amor privado ${ }^{177}$. Siguiendo la doctrina del Santo, se recuerda cómo es fruto del amor social, de una parte, la concordia fraterna y, de otra, la orientación constante del espíritu hacia la ciudad celeste y la preparación para ella ${ }^{178}$. La contemplación de Dios a que hace referencia el in unum, dice una autora, se enraíza en la purificación y trasformación del alma a que lleva el cumplimiento de la regla de oro 179.

El parágrafo ofrece un criterio valorativo, un indicador de perfección 180. Mientras una autora señala dos momentos, primero un paso ascético y luego un indicador de la conversión del corazón al amor social ${ }^{181}$, otro autor prefiere hablar de dos aspectos: uno negativo, el sacrificarse por los hermanos con un amor desinteresado, de auténtica caridad (1 Cor 13,5) que tiene en Cristo su primer modelo, y otro positivo: atender al interés de los demás, no al propio ${ }^{182}$. Otros todavía ponen de relieve cómo la propuesta agustiniana va en contra de algo que parece ser característico del hombre: atender mejor los propios asuntos que los comunes ${ }^{183}$. A pesar de ello, en el modelo monástico agustiniano hacer las cosas para uno mismo es una negación total de la entrega a Dios en la comunidad ${ }^{184}$. De ahí -se afirma- que tanto el complejo de superioridad como el de inferioridad reclaman un examen detallado a la luz de la "Regla de oro" para desenmascarar las intenciones o móviles de la acción y de la vida ${ }^{185}$.

176. TraPe, 140, con la referencia a Gn. litt. 11,15,20; ciu. 14,28; cf. también BoFF, 145; MARIE-ANCILLA, 102.

177. TRAPE, 141.

178. Trape, 142. Remite a en. Ps. 105,34; Marie-Ancilla, 107, que remite también a en. Ps. 105,34 .

179. MARIE-ANCILlA, 108. "Tous les frères qui peu à peu sont ainsi transfigurés forment... un lieu pour le Seigner, ce lieu où Dieu est contemplé" (ib. A continuación cita un texto de en. Ps. 131,5).

180. Cilleruelo, Comentario, 400-401, quien anota cómo el Santo se sirve de dos fórmulas paulinas que le impresionaron: Fil 2,21 y 2 Cor 5,15; MARIE-ANCILLA, 105.

181. MARIE-ANCILLA, 105.

182. MANRIQUE-SALAS, 192.

183. van Bavel, 73; Agatha Mary, 219: "This pattern is not one that now finds universal acceptance, since it can result in irresponsability, opportunism, and inmaturity; and it may well be that today common service in most things has to be offset by personal work in a few. But in all circunstances the spirit of Augustine's precept holds good; trustful sharing and concern for the well-being of others are the marks of love". Cf. también, Cilleruelo, Comentario, 400.

184. Agatha Mary, 219.

185. Cilleruelo, Comentario, 401. 
El precepto de esmerarse más en las obras comunes que en las propias es considerado como una declaración de guerra a toda actitud centrada en uno mismo ${ }^{186}$; un vivir ya aquí en la tierra la vida del cielo ${ }^{187}$. Pero se advierte que no basta con ponerse sin más al servicio de los otros, dado que también esto puede hacerse por egoísmo y que, por tanto, es imprescindible hacerlo bajo el impulso de la auténtica caridad, sinónimo de perfección ${ }^{188}$.

Como central y clave en el capítulo se valora la idea de progreso, dependiendo este del grado de amor al hombre que se tiene al lado, no a la "comunidad" en abstracto ${ }^{189}$. Pero los distintos autores no se ponen de acuerdo a la hora de juzgar la norma dada por el legislador. Medir el progreso por el criterio de cuidar mejor lo común que lo propio, uno lo considera como algo natural ${ }^{190}$, otro como una afirmación atrevida ${ }^{191}$, otro como un extraño criterio de vida espiritual. A quien se expresa de esta última manera le resulta curioso que la Regla ponga como uno de los indicadores de la vida espiritual de un religioso ese espíritu comunitario: cuanto más fraternos, más cristianos; cuanto más egoístas, menos espirituales 192. Detrás del criterio se percibe la idea de que la disponibilidad al sacrificio por el bien de la comunidad es expresión de un genuino amor al prójimo. Se le juzga como un camino seguro de perfección, que no requiere gestos extraordinarios, sino sólo la fidelidad de cada día; ni obras de penitencia, sino sólo un amor que sirve sin horarios, junto con un espíritu de sacrificio, don de Dios 193.

Por supuesto, el motivo de la caridad está presente en primera línea en todos los comentarios. Se llama la atención sobre el hecho de que la Regla

186. Zumkeller, 94. Para explicitar la idea, se sirve de 2 Cor 9,6; Fil 2,21 y de en. Ps. 132,6 у op. mon. 25,32 .

187. SAge, 243-244, que remite a en. Ps. 105,34. Se trata de la locura de la cruz (cf. 1 Cor ‘ 10,24; Fil 2,4-5; 1 Cor 13,5), en contraposición a un autor moderno que considera una locura instaurar un orden de cosas en que lo personal no fuera el resorte principal.

188. MANRIQUE-SALAS, 192.

189. VAN BAVEL, 75. Remite a op. mon. 25,32. "The use of proficio is telling, because it means more than progress in the sense of gaining ground; it also carries the meaning of rendering service and making a contribution" (AGATHA MARY, 224).

190. TRAPE, 142.

191. ZUMKELLER, 94.

192. BoFf, 146. Continúa: "¡Caricaturescas figuras de religiosos de gran piedad y mística con su ombligo como centro del mundo!". A continuación saca conclusiones desde la situación social de América Latina, desde donde escribe el autor. Por otra parte, lo que en realidad sorprende es que al autor le resulte curioso tal criterio.

193. ZuMKeller, 95. Como explicación, aduce 1 o. eu. tr. 65,2. "A sacrificial concern for the monastic community shows that our own love for God and neighbor is genuine" (ib.). 
habla poco de la caridad y mucho de la vida común y como razón se aduce que, para el Santo, vida común y caridad son términos sinónimos en la vida monástica ${ }^{194}$. Se concede importancia al hecho de que el parágrafo esté centrado sobre el capítulo 13 de la primera carta a los Corintios, donde san Pablo reconoce en la caridad la vía superior, con un movimiento eminentemente pascual y de dimensión trinitaria ${ }^{195}$. A partir de aquí, no falta quien presenta la caridad como el centro de la vida religiosa; de ella debe proceder y a ella debe orientarse con un perenne movimiento de causalidad circular todo pensamiento, afecto, actitud y acción. Un programa que se juzga solemne, pero difícil, puesto que la caridad es la más ardua y vulnerable de las virtudes ${ }^{196}$. Otro autor la muestra como la suprema norma reguladora de las más diversas actividades de la vida religiosa, tanto materiales como espirituales; de hecho, el servicio de amor a los hermanos no puede limitarse a los bienes materiales ${ }^{197}$. Otro ve en ella la viga maestra de todo el edificio espiritual y humano, indicando al mismo tiempo la extraña precisión y la forma insuperable como la Regla formula la centralidad absoluta del amor ${ }^{198}$. En este contexto, se contrapone el carácter definitivo de la caridad al pasajero de las necesidades a las que sirve. Una vez revestidos de la inmortalidad, ya nadie necesitará nada, y sólo le quedará la caridad y con ella el mérito de todas las acciones inspiradas por ella ${ }^{199}$. Esto da pie para valorar la actividad terrena: toda preocupación temporal por los demás adquiere un valor eterno, porque el amor es un elemento constante en la mitigación de las necesidades pasajeras de aquí abajo ${ }^{200}$. Y en este contexto resulta fácil introducir los temas del camino y de la patria, de la actividad y la contemplación simbolizadas por Marta y María, y la doctrina del usar y del gozar (uti/frui) 201.

El texto del parágrafo abre paso también a la reflexión sobre el trabajo ${ }^{202}$. Quien ha señalado que cumplir la regla de oro significa vivir ya aquí en la

194. MANRIQUE-SALAS, 187. La prueba la aporta una variante textual de indudable importancia, a propósito de 1 Cor 14,14. Donde san Pablo escribe: Haced todo con caridad (in caritate), san Agustín escribe: Haced todo en común (in commune). El obispo de Hipona hace la sustitución porque creía equivalentes los términos.

195. MARIE-ANCILLA, 108.101.

196. TRAPE, 137.

197. Manrique-Salas, 193; Agatha Mary, 220; Cilleruelo, Comentario, 401.

198. BOFF, 147

199. SAGE, 244-245.

200. VAN BAVEL, 74.

201. MARIE-ANCILA, 106.108; TRAPE, 143 que remite a doctr. chris. 1,24,24.

202. AgATHA MARY, 220-222. 
tierra en cierto modo la vida del cielo, se apresura a añadir que ello no implica una dispensa de la ley del trabajo, sino que, más bien, lo estimula por tener en Dios la recompensa ${ }^{203}$. Considerado el trabajo dentro del parágrafo, no cabe sino verlo como expresión de amor ${ }^{204}$, desde el cual queda valorizado 205. Como cabía esperar, se indica el modo cómo ha de realizarse: desde la preocupación por el bien material y espiritual de los demás y por su libertad, más que por uno mismo y la propia libertad ${ }^{206}$. La breve referencia al trabajo que se halla en el parágrafo, leída a la luz de la obra El trabajo de los monjes, da pie a una crítica contra el aburguesamiento y el parasitismo que pueden darse en los monjes. Por otra parte, para explicar que la Regla sea tan breve respecto a un tema tan fundamental en la tradición monástica, se aduce que el legislador da por hecho que se conoce la obligación del trabajo y que, por tanto, se limita a definir el espíritu con que han de realizarlo los siervos de Dios: teniendo siempre en el punto de mira el ideal de la comunidad ${ }^{207}$. En los textos agustinianos se ve ya anunciado el posterior ora et labora de la tradición benedictina ${ }^{208}$. Por último, y ahora mirando al presente, se pone de relieve la importancia de trabajar en común ${ }^{209}$.

\subsection{Parágrafo tercero}

La novedad que en el conjunto del capítulo aporta este parágrafo, juzgado por una autora como aparentemente superficial ${ }^{210}$, es la entrada en escena del superior que continúa jugando el papel principal en las cuestiones de colada, baños y salidas, como antagonista de la voluntad propia de cada uno y campeón del bien verdadero, individual y colectivo ${ }^{211}$. Su función es, en principio, administrativa 212.

203. SAGE, 243-244, que remite a en. Ps. 105,34.

204. Agatha Mary, 223.

205. BOFF, 147.

206. VAN BAVEL, 74. El autor señala cómo la interpretación agustiniana de 1 Cor 13,5 está más cercana al sentido original del texto que ciertas traducciones modernas, porque el amor es esencialmente desprenderse de uno mismo para acercarse al otro (ib.). Con motivo de 1 Cor 13,5, se sirve de otros textos del mismo capítulo paulino.

207. BoFr, 144.

208. BOFF, 144.

209. Agatha Mary, 220.

210. Agatha Mary, 228.

211. DE VOGÜÉ, $3,194$.

212. Agatha Mary, 228. "This present reference to him is the point at which administration (attention to the opus of the others) begins to give way to personal caring (attention to necessitas). But his personal caring should always have implicit in it the personal caring of the whole community whose representative he is in relation to each member" $(i b$.). 
En su aspecto material está claro que el parágrafo regula la recepción de donativos por parte de los siervos de Dios que moran en el monasterio. Nada más natural, pues, que establecer la comparación, de convergencia y divergencia a la vez, con el parágrafo undécimo del capítulo cuarto, que menciona determinados regalos que los siervos de Dios podrían recibir 213

A un nivel superior, lo preceptuado se ve como otra modalidad de vivir la regla de oro ${ }^{214}$, como caso-símbolo de la gran "ley de comunión", como una aplicación particular del principio de que el bien común ha de prevalecer sobre el privado, y la prueba de que la comunión de bienes no admite excepciones. El autor que así se expresa no encuentra en la Regla ningún otro pasaje en que las exigencias de la "socialización religiosa" aparezcan con más vigor y radicalidad 215 .

Para explicar el contenido del parágrafo se aducen razones teológicas, morales y psicológicas. Desde la teología se afirma que los lazos de la antigua familia no pueden ser más fuertes que los de la nueva (cf. Mc 3,31-35) 216. La moral juzga que recibir secretamente donativos en este contexto es una manifestación de egoísmo más que un robo ${ }^{217}$. La psicología, desde una perspectiva, ve la distribución de los bienes dentro del monasterio como un medio importante para dar a cada miembro el sentido de lo que él significa, teniendo en cuenta que el amor necesita ser capaz de dar, pues el donativo es expresión de la profunda interdependencia de la comunidad 218; desde otra, constata cómo muchas personas tras haber renunciado a una considerable propiedad, se apegan a insignificancias 219.

Lo preceptuado se interpreta en el contexto de la pobreza evangélica, cuyo objetivo es vencer todo espíritu egoísta y posibilitar la plena entrega en el amor a la comunidad y a las tareas caritativas o apostólicas ${ }^{220}$. En la

213. Agatha MARy, 225: "In the previous chapter, the reason for this was the safeguarding of a member who might be establishing an undesiderable relationship outside the monastery; here, the concern is for the building up of relationships within the common life... Earlier... the distribution and sharing of goods contributed to the unity of the monks; here, sharing is an expression of love that can look at others not only with compassion, but also with understanding". Cf. también DE VOGÜÉ, 3,192.

214. MARIE-ANCILLA, 109.

215. BOFF, 148.

216. BOFF, 148.

217. MARIE-ANCILLA, 109

218. Agatha Mary, 227.228.

219. ZUMKELLER, 93.

220. ZUMKELLER, 93. 
misma línea, se pone de relieve la exigencia de una absoluta fidelidad al ideal de la pobreza, que implica que nadie puede reclamar derechos ni disponer a capricho de los donativos 221 . A ese propósito se recuerda cuál fue el modo de proceder del Santo ${ }^{222}$.

Pensando en la práctica, algún autor habla de la perplejidad que suscita una determinación tan radical, para entrar luego en casuística y acabar señalando, con el recurso a Mt 5,39-41, que no se trata de leyes que hayan de ser tomadas al pie de la letra sino de ejemplos "paradójicos" que indican una línea ideal de conducta, casos-símbolo que sugieren una disposición interna radical 223 .

Nos queda la frase que cierra el parágrafo, no reconocida como auténtica por L. Verheijen en su edición crítica. Sentencia muy fuerte, pero que responde plenamente al pensamiento del Santo, extremadamente severo en temas de pobreza, dictamina un autor 224 . En realidad, no hace sino realzar aun más la radicalidad de la gran ley de la comunión de bienes y, leída desde la teología de la liberación, sacar las últimas consecuencias del "comunismo religioso", comenta otro. En su formulación chocante, la ve como la expresión más admirable de la suma seriedad con que la Regla trata las infracciones a la gran ley 225 .

\subsection{Parágrafo cuarto}

El parágrafo es interpretado como una aplicación de la "regla de oro" a una situación concreta. Lo esencial no es preocuparse por interés personal de la propia ropa, sino obrar según lo determinado para todos: lo que sobre todo hay que buscar es la limpieza del alma, que la caridad se sobreponga a los intereses personales ${ }^{226}$. Las aberraciones de determinados círculos monásticos que consideraban el descuido del aspecto exterior de la persona como un ideal dan pie para ponderar la prudencia que preside las instrucciones del legislador de Hipona. La belleza del alma no está reñida

221. ZUMKELLER, 92-93.

222. ZuMKELleR, 92-93; MARIE-ANCILlA, 172; BofF, 149. Todos estos autores remiten a s. 356,13, completado, en el caso del último, con la referencia a ep. 363, donde se ve cómo san Agustín no rehúsa llevar una túnica que le había tejido Sápida. "La delicadeza humana, la más fina flor del amor; aquí pasa delante de cualquier otra ley" ( $i b$.$) .$

223. BOFF, 148.

224. TRAPE, 150 .

225. BofF, 149, que trae a cuento la afirmación de Proudhon: "La propiedad es un robo", para añadir él: "La Regla no tiene otra visión".

226. MARIE-ANCILLA, 109. 
con la limpieza del cuerpo y del vestido; al contrario, se manifiesta también en ella 227 .

Pero de un extremo se puede pasar al otro, y el interés por lo exterior puede llegar demasiado lejos. De ahí que la intención del legislador sea, para un autor, evitar que el capricho personal juegue su parte en el interés por lo exterior e impedir que se convierta en fuente de manchas morales 228; para otro, más anclado en las categorías de la pobreza monástica, se trata de que nadie cuide de su ropa por simple interés personal, con el objetivo de prevenir todo retorno al espíritu de propiedad 229. Para un tercero, que tiene ante sus ojos el peligro de la vanidad, el valor de la norma no está en el problema trivial de quién debe lavar la ropa, sino en el del espíritu con que se debe actuar al respecto: dar más importancia al aseo interior que al exterior ${ }^{230}$. Otro autor todavía advierte un doble peligro detrás de lo ordenado: el de la falta de pobreza y el de la lujuria. De una parte, considera que el descontento que subyace al parágrafo destruye la conciencia de la total dependencia de la providencia de Dios, fundamental en la pobreza monástica 231; de otra, establece una relación entre el excesivo deseo por tener el vestido limpio y el empleo del término adpetitus (deseo), el utilizado en el parágrafo cuarto del capítulo cuarto para indicar el desear a mujeres 232 . Pero, en última instancia, el legislador busca plantear la cuestión sobre dónde tiene su corazón el siervo de Dios; si no lo tiene en Dios, no está limpio ${ }^{233}$. Otro autor, por último, prefiere dar realce a la contraposición entre lo interior y lo exterior ${ }^{234}$.

227. ZUMKELLER, 97.

228. ZuMkeller, 97, que a continuación cita a Posidio (Vita Augustini, 22); cf. también AgAtHa MARY, 230, que habla de la impureza interior del corazón de quienes se quejan de cómo se les da la ropa.

229. SAGE, 246.

230. BOFF, 150, que remite a Mt 23,26, y a la libertad y moderación con que san Agustín cuidaba este punto, tal como lo indica san Posidio (Vita Augustini, 22).

231. Agatha Mary, 232.

232. Agatha Mary, 230.

233. Agatha Mary, 230, con referencia a Mt 15,10-20.

234. De VoGǘ, 3,194, quien remite a san Jerónimo (ep. 108,20).

A propósito del presente parágrafo y de los que le siguen escribía hace ya algunos años C. Vaca: "Si el santo de Hipona es el genio de los grandes principios de la espiritualidad, no es menos profundo en el acertar a señalar los detalles a través de los cuales el espíritu ha de revelarse y convertirse en vida cotidiana... ve aquí la aplicación de los principios de caridad, espíritu de comunidad y búsqueda de Dios" (Compañía, servicio, cultura, en Revista Agustiniana de Espiritualidad 2 [1961] 179-191: 179). 


\subsection{Parágrafo quinto}

El núcleo del parágrafo lo constituye la asistencia a los baños. En su conjunto los autores contraponen la postura relativamente abierta de san Agustín a otra, mucho más cerrada, de los círculos ascéticos en general 235. Y desde una perspectiva histórico social, alguno ve posible interpretar la norma agustiniana como una protesta social contra el lujo, la riqueza y la ociosidad de unos pocos privilegiados 236 .

Como era de esperar, todos los comentaristas ponen el adecuado énfasis en la importancia concedida por el legislador a la salud de los siervos de Dios, quienes han de mantener el término medio entre el descuido imprudente y la ansiedad obsesiva ${ }^{237}$. El cuidado de la salud es valorado como intención de fondo que anima la Regla ${ }^{238}$, como la única justificación de la asistencia a los baños 239 . Estos constituyen, pues, una medida terapéutica 240. Tampoco se olvida en este contexto de salud la constitución débil del legislador, tomándola como argumento para explicar tanto el interés, característico de la Regla, por el enfermo y el débil, como el equilibrio conseguido 241 .

Los autores insisten asimismo en el criterio que regula la asistencia a los baños, que no es otro que el de la necesidad, la utilidad o la simple conveniencia ${ }^{242}$, a nivel individual ${ }^{243}$. Eso significa que no ha de ser el capricho personal del siervo de Dios, sino el juicio sabio del médico quien determine si procede o no ${ }^{244}$. Seguir lo que él prescriba se entiende incluido dentro de la obediencia monástica ${ }^{245}$. Una autora anota como interesante y sorprendente que la primera mención de la obediencia en la Regla y la primera aparición del prepósito en el ejercicio de su autoridad (iubente praeposito) acontezca precisamente en relación con la enfermedad. Deta-

235. van Bavel, 72; Zumkeller, 98; Sage, 247; BofF, 151; Agatha Mary, 234; Marie-AnCilla, 182; Cilleruelo, Comentario, 414.

236. VAN BAVEL, 72.

237. ZUMKELLER, 98.

238. BOFF, 151-152.

239. BOFF, 151; AGATHA MARY, 235;

240. BoFF, 151-152, quien la contrapone a la medicina preventiva, ausente de la Regla.

241. ZUMKELLER, 98; MARIE-ANCILLA, 179.

242. Zumkeller, 98; Sage, 247; van Bavel, 72; Agatha Mary, 235; Marie-AnCilla, 181.

243. Agatha Mary, 235.

244. ZuMKELLER, 98; SAGE, 247.

245. ZUMKELLER, 98; SAGE, 247. 
lles que explica por la naturaleza de lo que está en juego, que requiere decisiones firmes. De hecho, el punto de vista del paciente puede estar distorsionado por la enfermedad ${ }^{246}$. Lo que se haga nunca ha de estar motivado por una cupiditas, sino por su grado de contribución al bienestar de la persona ${ }^{247}$.

El precepto de obedecer "sin murmurar" al médico brinda la oportunidad, en un caso, para exponer los efectos negativos de la murmuración, signo de desunión y cuya ausencia es un aspecto del amor ${ }^{248}$, y en otro, para introducir cuál ha de ser la recta relación con el médico ${ }^{249}$. Haciendo una aplicación para el presente, se ofrece el criterio siempre válido: cuidar la salud ${ }^{250}$.

\subsection{Parágrafo sexto}

En este parágrafo el legislador fija una doble directriz. La primera, referida al hecho de la enfermedad: se ha de creer al siervo de Dios que afirma sufrir alguna dolencia; la segunda, referente al tratamiento adecuado: si existe duda respecto de la eficacia del que solicita el paciente, se ha de consultar al médico.

La primera de ellas se explica ya desde el horror del Santo a la mentira 251 ; desde el afecto y la delicadeza para con el otro, al que ha de creerse sin dudar, pues nadie mejor que uno mismo conoce el propio cuerpo 252; o desde la confianza ${ }^{253}$. Se pone de relieve la exigencia de creer al siervo de Dios, aun sin olvidar que pueda estar mintiendo 254 o que esté engañado él mismo. También en estos casos se ejercitan las virtudes auténticas 255 . Merece asimismo especial atención el "sin dudar" 256.

246. Agatha Mary, 233. "But the discernment of what is in one's own best interests is a very difficult thing, and for that reason there is value in the possibility of questioning and censure by others. While in many areas there can be a fairly objective stance, for most people there remains a certain field of self-knowledge and sensitivity that is heavily clouded; it is here that a religious is to some extent safeguarded by his or her community" (ib. 235).

247. Agatha MARy, 235.

248. AgATHA MARY, 236.

249. SAGE, 247.

250. BoFF, 152.

251. SAGE, 247.

252. BoFF, 152-153.

253. AgAtha MARY, 237.238.

254. BOFF, 153.

255. Cilleruelo, Comentario, 415.

256. Agatha Mary, 238. La autora prefiere el término "hesitación" en lugar del más fuerte "duda". Y explica: "That does not mean that what he says is to be believed explicity but that his condition, real or imagined, is to be considered seriously - which is not the same thing as to say that it is to be considered serious" (ib.). 
En sí misma la norma es valorada como una admirable intuición del legislador, cuya agudeza de miras penetra hasta las profundidades del hombre, abriendo el espacio a Freud 257. Se habla incluso del "seguro instinto" del legislador 258. Y mirando a nuestro presente, se juzga que esta directriz de la Regla tiene una aplicación sorprendente en relación también con los trastornos psicológicos 259 .

La segunda directriz se fundamenta en una justificada desconfianza en los remedios autoaplicados; en esos casos, se juzga que el médico representa una instancia de objetividad ${ }^{260}$. De él se afirma que, en el ejercicio de sus funciones, queda revestido de un prestigio casi religioso, ante el que quedan anuladas las opiniones del enfermero y de los demás ${ }^{261}$. Detrás de toda esta normativa se ve en el legislador a un fino psicólogo 262.

\section{8. Parágrafo séptimo}

El legislador dispone que los siervos de Dios salgan siempre acompañados por uno o dos hermanos. La reflexión de los comentaristas se orienta a dar razón de lo dispuesto. Unos aducen razones morales, otros espirituales. Hay quienes piensan que el legislador, sabedor de que las casas de baños eran lugares de rampante inmoralidad, toma una medida de precaución y protección ${ }^{263}$. Otros piensan que la norma se inspira en una preocupación por el orden y la prudencia, y la colocan en el mismo contexto que

257. BOFF, 153.

258. Agatha Mary, 238

259. BOFF, 153.

260. BOFF, 153.

261. Cilleruelo, Comentario, 415.

262. BOFF, 153.

263. ZUMKELLER, 98, quien remite a cat. rud. 16,25; AGATHA MARY, 239, quien no olvida otro aspecto: "the mention of two or three again here... seems to point to their double function: the sight of monks together was to be seen by others as an apostolic gesture -they were behaving in a "monkly" manner, however compromising might be the place where they were seen, and the companionship of a group of monks was a safeguard against illicite behavior iniciated by one of them or by anyone else whom they might happen to meet" (ib. 240). Cf. también C. VACA, Compañía, servicio, cultura, en Revista Agustinia de espiritualidad 2 (1961) 179-191: 181.

L. Verheijen, sin embargo, después de examinar los diferentes textos de la obra agustiniana en que el santo habla de los baños apunta en la dirección contraria. Dichos textos nos hacen comprender que el santo hablaba sin complejos de los baños públicos con sus costumbres a gentes que no tenían aprehensiones en este campo. Tras referirse a cat. rud. 16,25, continúa: "La sérénité avec lequelle saint Augustin parle partout ailleurs des thermes fait penser que les moeurs n'y étaient pas malsaines, malgré la nudité qui y était une sorte de nécessité de societé" ("Non pas à moins de deux ou trois", en Augustiniana 32 (1982) 255-262: 259.262 NA 2, 166-173: 170.173. 
llevó al Santo a fustigar a los monjes vagabundos en la obra El trabajo de los monjes 264; al ir juntos con la modestia propia de su estado, difundirán -se afirma- el buen olor de la santidad y suscitarán vocaciones 265 . Otros ubican la norma en el corazón mismo del espíritu de la Regla. L. Verheijen señala cómo el precepto de ir acompañados no se refiere sólo a las salidas a los baños, sino a cualquier otro lugar a donde fuera necesario ir. Los baños sirven sólo como ejemplo de un posible destino. Por tanto, la respuesta a la necesidad de tener que salir siempre acompañados, escribe el docto agustino, se halla en el conjunto de la Regla. Desde su primera línea el autor ha insistido en el carácter comunitario de la vida de aquella santa sociedad. Las salidas deben tener, pues, una dimensión comunitaria. Y a la pregunta de por qué el legislador habla específicamente de la salida a los baños y no de otra, escribe: "Yo supongo que san Agustín ha querido amueblar el "no hacer nada", inevitable en los baños, con conversaciones respetables" 266 . Este modo de ver las cosas lo han hecho suyo otros autores 267 .

La disposición concreta de que sea el prepósito quien señale con quiénes se ha de salir se interpreta de distinta manera. Tras la indicación de que quien deba salir no ha de elegir su compañero, alguien ve un aire de sospecha, por desagradable que pueda resultar, explicable por la experiencia de situaciones difíciles vividas 268 ; otro autor, en cambio, excluye todo atisbo de vigilancia y lo interpreta como un medida para asegurar y favorecer entre los hermanos una relación sin discriminaciones y exclusivismos, desde la experiencia de cuán perjudiciales son los grupos cerrados. Según él, la norma está inspirada por el ideal de una fraternidad abierta y mutuamente responsable, y una pedagogía evangélica 269.

Como cabía esperar, la norma se lee también mirando al presente. De una parte, se reconoce que, dadas las condiciones de la vida moderna, resulta en buena medida impracticable; de otra, que se puede mantener el espíritu de la misma, cuando quien sale solo a su tarea la realiza en espíritu

264. Cf. op. mon. 28,36 .

265. SAGE, 247-248.

266. "Non pas à moins de deux ou trois", 262: NA 2,173. Y recuerda que los diálogos de Casiciaco tan tenido en parte su origen en diálogos de estas características.

267. Cf. Cilleruelo, Comentario, 415; BofF, 154-155, quien insiste en la comunión fraterna, que se ha de hacer realidad incluso fuera de casa y que implica la responsabilidad mutua en todos los ámbitos, no sólo en el de la castidad. Al mismo tiempo coloca la norma en la tradición de la lex socii de san Pacomio (cf. antes, nota 94).

268. Agatha MaRy, 241.

269. BoFF, 155. 
de comunión con la comunidad y cuando la comunidad le acompaña con su oración 270 .

\section{9. Parágrafos octavo-undécimo.}

Los últimos cuatro apartados tienen en común el legislar a propósito de los distintos oficios. Se constata que la vida común exige organización y determinados servicios públicos que han de ser atendidos 271 . Se pone de relieve, de un lado, el necesario espíritu de servicio, solicitud, puntualidad y caridad que debe caracterizar su ejercicio y que determina su valor; de otra, la consideración de que cada oficio es un servicio a la comunidad y de que, por tanto, ha de estar regulado por la regla de oro presentada en el parágrafo segundo del presente capítulo ${ }^{272}$. Como argumentos se aducen Mt 25,35-40 y, para los casos difíciles, 2 Cor 9,7; el principio es servir a los demás como uno quiere que le sirvan a él ${ }^{273}$. Desde la perspectiva de los siervos de Dios no encargados del oficio, se señala que no atañe al monje que ha hecho voto de pobreza servirse personalmente; lo que necesita lo recibe del superior por medio de los encargados 274 . Se advierte sobre el posible descontento, ya sea referido a las personas puestas al frente de los respectivos servicios, ya sea por el modo de cumplir con el oficio, ya porque nunca faltan siervos de Dios insatisfechos y disconformes con todo 275 .

Por lo que se refiere específicamente al parágrafo octavo, se señala la delicadeza de la Regla o la sensibilidad del legislador que no olvida ni a los que sólo sufren una indisposición, aunque sea pasajera ${ }^{276}$. En este corto parágrafo se ve estimulada la sensibilidad en quienes tienen a su cargo atender al enfermo ${ }^{277}$. A la pregunta de por qué hay un sólo responsable se responde: para evitar confusiones y tratamientos contradictorios 278 . Se

270. BofF, 154-155. Recalca además que, aunque sólo sea por razones prácticas, la comunidad ha de saber dónde anda cada uno de sus miembros. CillereuElo, Comentario, 415: "Estas prescripciones, como coyunturales, cambian con los tiempos y lugares, y será suficiente mantener el espíritu de comunidad". Cf. también p. 408, extendido el juicio al contenido de los parágrafos 4-11.

271. Cilleruelo, Comentario, 416.

272. ZUMKELLER, 101.103, quien pone como ejemplo al mismo san Agustín al aceptar el ministerio sacerdotal; SAGE, 248; TRAPE, 165:

273. SAGE, 248-249. Remite también a ep. 40,4; en. Ps. 103,1,19

274. SAGE, 248.

275. Sage, 248; Cilleruelo, Comentario, 417.

276. BofF, 156; Agatha Mary, 242.

277. Agatha Mary, 244.

278. BoFF, 156, quien añade que no queda excluido personal auxiliar. 
anota cómo la medicación principal indicada es la comida ${ }^{279}$. Se juzga que todas las tareas han de ser dadas en confianza, tema que subyace a este parágrafo, pero no se oculta que existen causas para la desconfianza, que se pueden superar con el amor 280.

A propósito del parágrafo noveno, se observa que en él encontramos la primera referencia explícita al servicio a los hermanos, extendido a diversos aspectos de sus vidas. En el presente parágrafo el servicio aparece como un aspecto de la fraternidad 281 ; se pondera particularmente el precepto de servir sin murmurar ${ }^{282}$, con reflexiones sobre la murmuración misma 283 . El modo de actuar del legislador en este parágrafo se juzga más delicado que en el parágrafo anterior y se señala cómo asume que cuanto demandan los siervos de Dios es necesario. En cuanto siervos de Dios, su actividad radica en un esfuerzo continuo por alcanzar la unidad de mentes y corazones en fidelidad a la vida de oración y de culto ${ }^{284}$.

El parágrafo décimo se convierte en ocasión para que los autores hablen de la importancia que asignaba el legislador al estudio en el monasterio. Con el epígrafe "el servicio de la inteligencia" describe un autor el contenido del presente parágrafo, que -afirma-, esconde más de lo que parece 285 . La severa disposición respecto de quiénes piden los libros a deshora se enmarca en el interés que mostró el Santo por ellos y en el hecho

279. BoFf, 156, que señala cómo el legislador se mantiene fiel a la medicina antigua, según la cual el alimento es mejor medicina, y en el asignar como remedio para cada enfermedad un alimento específico, hecho en que ve una ulterior prueba de la amplitud de miras de la Regla.

280. AGATHA MARY, 243: "So many people are involved in trusting relationships here. The prior must trust the monk he chooses to look after those who are ill; there needs to be trust between patient and helper; hand there has to be trust between the later and those who are in chage of storeroom if the patient is to get the nourishment that he needs; then, if food has to be prepared, the monks working in the kitchen and scullery are also involved".

281. AgAtHa MARy, 246, que añade reflexiones sobre la fraternidad en la Regla, fraternidad que, a su vez, ofrece el contexto para cada acto de servicio. "So when in the present passage of the Rule Augustine uses this same word he is appealing to an awareness, in each member of the community, of an obligation and responsability as well as an awareness of fellowship".

282. BofF, 156, que remite a 1 Cor 10,10 y 2 Cor 9,7. "Bella y oportuna recomendación... ¡Servir con presteza y cortesía, de buen corazón y hasta con alegría, además de difícil es necesario!" (ib.); TRAPÉ, 165: "Commando breve (servir sin murmurar), ma capace, se osservato, di rendere serena e gioiosa la vita comune. Evidentemente questo servizio di carità fraterna dovrà essere reso secondo le disposicioni generali della Regola e della comunità".

283. BOFF, 157.

284. Agatha Mary, 245-246.

285. BOFF, 172. 
de que eran un bien precioso que merecía todos los cuidados, puesto que no eran de fácil adquisición ${ }^{286}$. La medida se entiende también como un aviso de que los libros no eran pertenencia particular de nadie, como un quita excusas para no trabajar ${ }^{287}$ y como un indicador indirecto de la importancia que san Agustín asignaba a la formación intelectual de sus monjes 288 . En el monasterio el estudio se estimulaba como una forma de trabajo, para conocer mejor la palabra de Dios, practicarla y enseñarla ${ }^{289}$. Esta atención al estudio se considera como una innovación para su tiempo, con gran influjo en el monacato posterior y en la cultura occidental ${ }^{290}$. Se valora el estudio como un índice de piedad ${ }^{291}$. El ejemplo del Santo se convierte en una invitación a una piedad eminentemente doctrinal 292.

Por último el parágrafo undécimo. Un autor llama la atención sobre la diferencia entre el parágrafo anterior y el presente: los libros están sujetos a un horario, mientras que la ropa y el calzado no, disposición que juzga de un realismo sorprendente, sobre todo viniendo de un genio intelectual. Este particular le permite insistir sobre el fino sentido de humanidad de san Agustín ante las necesidades humanas más elementales ${ }^{293}$. En el precepto se ve una voluntad de ordenar el cuidado y custodia del vestido, sin que haya rigidez alguna en su distribución y uso, desde una perspectiva diferente a la del parágrafo primero ${ }^{294}$. Se señala que san Agustín pone

286. BoFF, 158;

287. De VogüÉ, 3,195.

288. van BAVEL, 72, que remite a la información de san Posidio (Vita Augustini, 28 y 31); Agatha Mary, 249.

289. BOFF, 157. El autor ve allí lo que hoy se llama "apertura pastoral" de la vida religiosa. Aunque refiriéndose al monasterio de clérigos, A. Sage habla del estudio como principal ocupación de los monjes (SAGE, 249; cf. DE VOGÜÉ, 3,218 que incluye la referencia a ep. 243,6).

290. BOFF, 157. "En estas dos líneas escasas de la Regla se encierra una verdadera revolución de la vida monástica y religiosa hecha por san Agustín" (C. VACA, Compañía, servicio, cultura, p. 185).

291. Cilleruelo, Comentario, 417: "Una piedad que no incita al estudio ni lo promueve, ya como alimento espiritual, ya como medida de apostolado, es muy sospechosa, ya que la piedad de por sí va orientada al estudio como progreso de la misma piedad, como desarrollo y crecimiento que prepara la acción. Donde no se estudia, entran el ritualismo, el formalismo, la rutina, la simplicidad pueril y las almas vegetan en el marasmo de los "indoctos", como decía san Agustín".

292. SAGE, 249; Agatha Mary, 248.

293. BOFF, 158.

294. Agatha Mary, 251: "There (5,1) Augustine considered the varying attitudes of individual monks to what was given to them. Here, with much less need to point an admonitory finger, he addresses the monks who look after the community's goods and ensure that they are available for all the brothers". 
una delegación de autoridad en el trasfondo del servicio a la comunidad entera, medio para asegurar que cada miembro sea provisto de lo que necesita y cuando lo necesita, en un contexto de amor ${ }^{295}$.

\section{Valoración}

Al ser un capítulo largo, la síntesis de las aportaciones de los comentaristas tenía que resultar necesariamente larga también. Vamos a procurar, no obstante, que nuestra valoración sea breve. Para ello es imprescindible no entrar en los detalles y limitarnos a los aspectos más generales.

Los criterios empleados son varios: comunión de bienes, distribución proporcional de los mismos, pobreza, amor, etc.

No cabe duda de que los distintos preceptos contenidos en el capítulo se levantan sobre el doble principio de la comunión de bienes y de su distribución de acuerdo con las necesidades de cada uno. Pero, con ser cierto, nos parece que no lo dice todo. No basta con ordenar que a cada cual se le dé lo que necesite de los bienes de uso habitual. Su importancia tiene el saber quién determina lo que necesita cada cual. Ahora bien, en el capítulo vemos que no hay uniformidad a este respecto: en unos casos es el superior, en otros el médico, en otros la misma persona afectada, en otros los distintos "oficiales". ¿Responde esta diversidad a algún criterio o busca algún objetivo concreto? Es algo que no se encuentra en los comentarios. Por otra parte, ambos principios han sido formulados con la máxima claridad en el capítulo primero de la Regla. El dato reclama que se establezca alguna relación de convergencia o de divergencia, que explique el resurgir en este momento específico del documento. Pero es algo que tampoco aparece en los comentarios.

Otro criterio desde el que se ha interpretado el capítulo es el de la pobreza monástica. Evidentemente, cuanto determina el capítulo se enmarca dentro de un estilo de vida sobrio y austero. Es cierto que apenas se niega nada a nadie ${ }^{296}$, pero también lo es que en varios de sus parágrafos se insiste en el concepto de sólo lo necesario ${ }^{297}$. La mente del legisla-

295. Agatha MARy, 251-253. Habla de delegación de autoridad porque en praec. 1,3 y 5,3 aparece el prepósito como responsable de distribuir los bienes.

296. Si se exceptúa el baño a quien lo pide sin prescripción médica (praec. 5,5). Los libros en cuanto tales no se niegan; lo que se niega es su concesión fuera de tiempo.

297. “... quod cuique opus est...” (praec. 5,1, 1. 145); “... transitura necessitas" (ib. 5,2, 1. 159); “... inter necessaria deputandum... cui necessarium fuerit" ( $i b .5,3,1.164 .165)$; " ... ire necesse fuerit... qui habet aliquo eundi necessitatem" (ib. 5,7, 1. 180); "... quod cuique opus esse perspexerit" (ib. 5,8, 1. 184); “... quando fuerint indigentibus necessaria” (ib. 5,11, 1. 190-191). 
dor es, sí, que a nadie le falte nada que sea necesario, pero también que nadie tenga más de lo que le sea necesario. Sin duda alguna, en este sentido la pobreza atraviesa el capítulo de principio a fin. Pero no hay que olvidar otras perspectivas. Si se pone la pobreza en relación con el poseer/no poseer, no todos los parágrafos caben dentro de ese criterio. En varios de ellos, lo que se ventila es más bien quién debe hacer algo o cómo debe hacerlo 298. Unido a esto va el hecho, que nos parece significativo, de la ausencia en el capítulo de toda valoración de los bienes en sí mismos. El problema para el legislador no parece ser la relación del siervo de Dios con ellos, sino la relación entre las personas con ocasión de ellos ${ }^{299}$. En el capítulo los bienes no aparecen tanto como obstáculos en la relación entre el hombre y Dios como en la relación de unos siervos de Dios con otros. Y este aspecto no nos parece suficientemente clarificado.

Es indiscutible la importancia que juega el tema del amor en el capítulo, sobre todo teniendo en cuenta su parágrafo segundo. Pero, de una parte, en el comentario no siempre hemos visto establecer una relación inmediata y específica del contenido de cada parágrafo con dicho criterio. De otra parte, no hay que olvidar que, aunque la caridad es una, puede tener objetos diferentes (cf. Mt. 22,37-40) y establecer las oportunas distinciones puede ser esclarecedor. Por último, como ya indicamos, el amor no es algo que aparezca como exclusivo del presente capítulo, pues volverá a aparecer con fuerza en los dos capítulos siguientes. Por tanto, para ser tomado como criterio de interpretación del capítulo parece que tiene que ser considerado desde alguna perspectiva concreta.

A nuestro parecer, los comentarios no han logrado reflejar la "fisonomía" espiritual propia y específica del capítulo, a que responden todos y cada uno de los rasgos externos, es decir, de sus normas concretas. En síntesis dos son las objeciones de carácter general que creemos se pueden poner a los distintos comentarios: una, la falta de un criterio unificador de todos y cada uno de los parágrafos; otra, el no haber profundizado lo suficiente. Recurriendo a una imagen, se puede decir que la obra de los comentaristas responde más a una fotografía que a una radiografía del capítulo.

298. Así particularmente en los parágrafos cuarto, sexto y séptimo.

299. Habitualmente, a la hora de entrar en valoraciones de pobreza religiosa, se juzga esencial la clase de relación que la persona tiene con los distintos tipos de bienes, que se mide, negativamente por el grado de esclavitud frente a ellos o, positivamente, por el grado de libertad, también frente a ellos. 